\title{
Defects in Embryonic Neurogenesis and Initial Synapse Formation in the Forebrain of the Ts65Dn Mouse Model of Down Syndrome
}

\author{
Lina Chakrabarti, ${ }^{1}$ Zygmunt Galdzicki, ${ }^{2}$ and Tarik F. Haydar ${ }^{1}$ \\ ${ }^{1}$ Center for Neuroscience Research, Children's National Medical Center, Washington, DC 20010, and 2Department of Anatomy, Physiology, and Genetics, \\ Neuroscience Program, School of Medicine, Uniformed Services University of the Health Sciences, Bethesda, Maryland 20814
}

Trisomy 21, one of the most prevalent congenital birth defects, results in a constellation of phenotypes collectively termed Down syndrome (DS). Mental retardation and motor and sensory deficits are among the many debilitating symptoms of DS. Alterations in brain growth and synaptic development are thought to underlie the cognitive impairments in DS, but the role of early brain development has not been studied because of the lack of embryonic human tissue and because of breeding difficulties in mouse models of DS. We generated a breeding colony of the Ts65Dn mouse model of DS to test the hypothesis that early defects in embryonic brain development are a component of brain dysfunction in DS. We found substantial delays in prenatal growth of the Ts65Dn cerebral cortex and hippocampus because of longer cell cycle duration and reduced neurogenesis from the ventricular zone neural precursor population. In addition, the Ts65Dn neocortex remains hypocellular after birth and there is a lasting decrease in synaptic development beginning in the first postnatal week. These results demonstrate that specific abnormalities in embryonic forebrain precursor cells precede early deficits in synaptogenesis and may underlie the postnatal disabilities in Ts65Dn and DS. The early prenatal period is therefore an important new window for possible therapeutic amelioration of the cognitive symptoms in DS.

Key words: Ts65Dn; neocortex; hippocampus; synaptogenesis; mental retardation; cell cycle; development

\section{Introduction}

Down syndrome (DS), caused by triplication of human chromosome 21 (HSA21), occurs in 1 of every 732 live births (Canfield et al., 2006), and DS individuals have a wide range of abnormalities in many organ systems. Mental retardation, which can range from mild to severe (Chapman and Hesketh, 2000), is by far the most common phenotype in DS. Although the etiology of the cognitive deficits is not well understood, both prenatal and postnatal abnormalities have been found in the DS CNS. Neuropathological changes found from second trimester to birth include a smaller and hypocellular hippocampal dentate gyrus and cerebellum (Jernigan and Bellugi, 1990; Raz et al., 1995) as well as altered cortical lamination (Golden and Hyman, 1994). In addition, there are fewer synapses in the prenatal DS forebrain (Petit et al., 1984; Weitzdoerfer et al., 2001) and pyramidal neurons possess smaller dendritic arborizations in the cerebral cortex (Becker et al., 1986; Takashima et al., 1989; Benavides-Piccione et

Received March 28, 2007; revised Aug. 30, 2007; accepted Sept. 3, 2007.

This work was supported by The Dana Foundation (New York), the Research Advisory Council, Children's National Medical Center, Cellular Imaging Core support, a New Investigator Grant (P30HD40677) from the Mental Retardation Developmental Disabilities Research Center (T.F.H.).Z.G. was supported by Uniformed Services University of the Health Sciences (CO7OTC), The Jérôme Lejeune Foundation, and National Institutes of Health funding. We thank Robert McCarter and Jianping He for help with statistical analyses. We also thank Drs. Josh Corbin, Vittorio Gallo, Bruce Krueger, and Irene Zohn for critical reading of the manuscript and helpful discussions.

Correspondence should be addressed to Dr. TarikF. Haydar, Center for Neuroscience Research, Children's National Medical Center, 111 Michigan Avenue Northwest, Washington, DC 20010. E-mail: thaydar@cnmcresearch.org. DOI:10.1523/JNEUROSCI.3406-07.2007

Copyright $\odot 2007$ Society for Neuroscience $\quad$ 0270-6474/07/2711483-13\$15.00/0 al., 2004). Postnatally, the DS brain exhibits degeneration of cortical pyramidal neurons (Schmidt-Sidor et al., 1990), profound dendrite and synapse abnormalities (Marin-Padilla, 1976; Becker et al., 1986; Takashima et al., 1989; Wisniewski, 1990), and hypocellular hippocampus and cerebral cortex (Zellweger, 1977; Sylvester, 1983). However, because of the scarcity of tissue, all of the prenatal DS studies to date have been conducted late in gestation. It remains unknown whether abnormalities in early embryogenesis contribute to DS neuropathology.

Several mouse models that take advantage of the homology between HSA21 and mouse chromosome 16 (MMU16) have been created (see Fig. 1) (Kola and Hertzog, 1998; Dierssen et al., 2001; Galdzicki and Siarey, 2003; Seregaza et al., 2006). We previously discovered delays in neocortical development in the trisomy 16 (Ts16) mouse (Haydar et al., 1996, 2000; Cheng et al., 2004), but it is now accepted that the presence of non-HSA2 1 homologous genes in Ts16 prevents valid comparisons to DS brain development. In contrast to Ts16, the Ts65Dn mouse model (Reeves et al., 1995) survives birth and contains a high degree of synteny between the distal regions of HSA21 and MMU16 (94 of the 170 orthologous genes on HSA21 are triplicated in Ts65Dn) (Gardiner et al., 2003) and has therefore become the most studied trisomy 21 model. Postnatally, Ts65Dn mice exhibit multiple DS-specific symptoms including craniofacial dysmorphology (Richtsmeier et al., 2002), abnormal cerebellar and hippocampal development, and behavioral abnormalities (Insausti et al., 1998; Baxter et al., 2000; Olson et al., 2004; Lorenzi 
and Reeves, 2006; Roper et al., 2006). In addition, adult Ts65Dn animals exhibit defects in synapse formation, neurophysiology, and signaling pathways (Siarey et al., 1997, 1999, 2006; Belichenko et al., 2004; Kleschevnikov et al., 2004). However, it is unknown whether altered embryonic brain development underlies these postnatal defects. To address this possibility, we established a breeding colony dedicated to providing Ts65Dn embryos. We found a severe delay in cortical and hippocampal growth that precedes all other changes found during Ts65Dn development and that may underlie subsequent abnormalities in synaptic development and function.

\section{Materials and Methods \\ Animals}

Ts65Dn and euploid fetuses were generated by mating Ts65Dn females (originally obtained from The Jackson Laboratory, Bar Harbor, ME) with C57BL/6JEi $\times$ C3SnHeSnJ $(\mathrm{B} 6 \mathrm{EiC} 3) \mathrm{F}_{1}$ hybrid males. As illustrated in Figure 1, MMU16 is a composite of orthologous regions of several human chromosomes, including HSA 16, 22, 3, and 21. The distal segment of MMU16 triplicated in Ts65Dn animals contains a large region of the HSA21 orthologous region. Compared with the Ts1Cje and Ms1Cje murine models of DS, the Ts65Dn model contains the largest number of HSA21-homologous genes (Fig. 1). Ts65Dn mating couples were paired overnight for $16 \mathrm{~h}$ and then separated the following morning. The day of separation was designated embryonic day 0.5 (E0.5). Fetuses were removed from pregnant dams from E13.5 to E18.5, chilled, and decapitated immediately. For paraffin embedding, fetal heads were immersed in Bouin's fixative (Electron Microscopy Sciences, Hatfield, PA) overnight at $4^{\circ} \mathrm{C}$, whereas for frozen sections the heads were fixed on $4 \%$ paraformaldehyde (PFA). Tail tips $(2 \mathrm{~mm})$ were collected before fixation and genomic DNA was extracted for quantitative PCR (qPCR) genotyping. The brains in Bouin's fixative were removed from the calvarium and dehydrated through a series of ascending ethanol concentrations, cleared in Citrisolv (Fisher Scientific, Houston, TX), and embedded in paraffin. The PFA-fixed brains were cryoprotected in $30 \%$ sucrose for $2 \mathrm{~d}$ at $4^{\circ} \mathrm{C}$, and then frozen in OCT compound (Sakura Finetek, Torrance, CA).

\section{Real-time qPCR for genotyping}

The $2 \mathrm{~mm}$ tail tips were digested with $100 \mu \mathrm{g} / \mathrm{ml}$ proteinase $\mathrm{K}$ in DNA digestion buffer (50 mm Tris-HCl, pH 8.0, 100 mM EDTA, pH 8.0, 100 $\mathrm{mm} \mathrm{NaCl}$, and $1 \% \mathrm{SDS}$ ) for $1 \mathrm{~h}$ at $55^{\circ} \mathrm{C}$ and were then phenol/chloroform extracted. DNA was precipitated with absolute ethanol and dissolved in $10 \mathrm{~mm}$ Tris buffer, $\mathrm{pH}$ 8.0. Genotyping was performed by modification of the TaqMan-based qPCR method (Liu et al., 2003). Briefly, the gene for amyloid $\beta$ precursor protein $(A p p)$ and/or the myxovirus resistance 1 $(M \times 1)$ were used as the target (marker) gene, whereas the apolipoprotein $\mathrm{B}(A p o B)$ gene was used as the internal control. The rationale for this methodology is that $A p p$ and $M x 1$ are located in proximal and distal ends, respectively, of the MMU16 segment, which is triplicated in Ts65Dn, whereas $A p o B$ is found in MMU12. Thus, Ts65Dn samples have three copies of $A p p$ and $M x 1$, whereas euploid samples have only two copies. In contrast, both Ts65Dn and euploid animals have two copies of $A p o B$. The extra copy of App or $M x 1$ in trisomic samples is detected by qPCR. After amplification, the average change $(\Delta)$ in cycle threshold (CT) of the target gene $A p p$ or $M x 1$ from that of $A p o B$ was calculated $\left(\triangle \mathrm{CT}=\mathrm{CT}_{A p p / M x 1}\right.$ $\left.-\mathrm{CT}_{A p o B}\right)$. The $\triangle \mathrm{CT}$ value for App in trisomic samples typically range between -0.5 and -0.75 , whereas for $M x 1$ it ranges between -1.0 and -1.2. The sequences of primers and probes for App were as follows: forward primer, $5^{\prime}$-TGCTGAAGATGTGGGTTCGA-3', reverse primer, 5'-GACAATCACGGTTGCTATGACAA-3', and probe, 5'-FAMCAAAGGCGCCATCATCGGACTCA-BHQ1a-3' (Operon, Huntsville, $\mathrm{AL})$. The sequences of primers and probes for $M x 1$ were as follows: forward primer, $5^{\prime}$-TCTCCGATTAACCAGGCTAGCTAT-3', reverse primer, 5'-GACATAAGGTTAGCAGCTAAAGGATCA-3', and probe, 5'-FAM-TGGCTTTCCTGGTCGCTGTGCA-BHQ1a-3'. The sequences of primers and probes for $A p o B$ were as follows: forward primer, 5'-CACGTGGGCTCCAGCATT-3', reverse primer, 5'-TCACCAGTCATTTCTGCCTTTG-3', and probe, 5' -Texas Red-CCAATGGT-

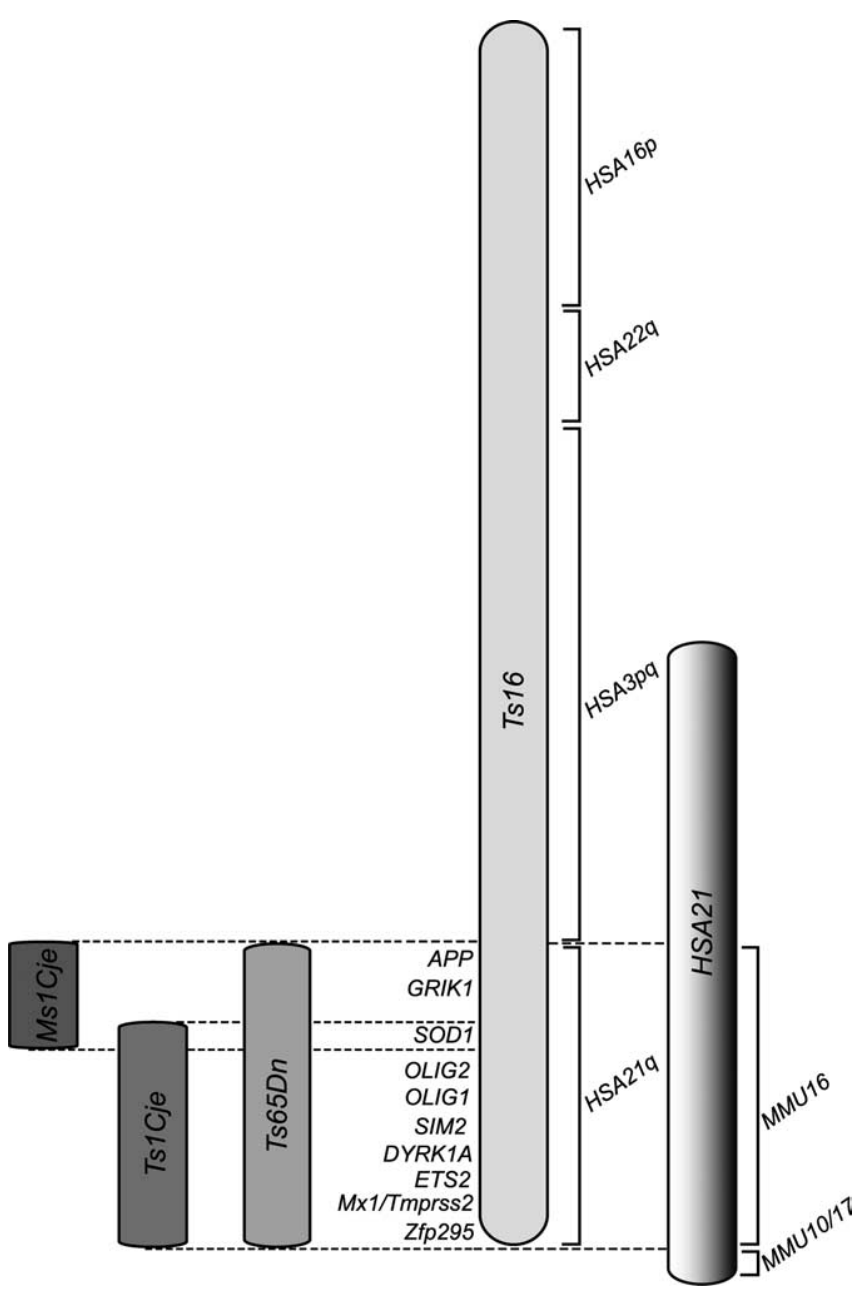

Figure 1. Schematic illustration of the synteny between human chromosome 21 (HSA21) and mouse chromosome 16 (MMU16). MMU16 is orthologous to segments of 10 different human chromosomes, some of which are depicted in Fig. 1. Specifically, 51, 19, 17, and 10\% of all mouse chromosome 16 genes are orthologous to human chromosomes 3, 21, 16, and 22, respectively (based on http://www.informatics.jax.org/, August 24, 2007). The remaining 3\% of mouse chromosome 16 genes are orthologous to human chromosomes 2, 8, 10,12, 13, and 17. The Ts 16 model contains an extra copy of the entire MMU16, whereas Ts65Dn contains a partial triplication of the distal region of MMU16 syntenic to the long arm of HSA21. Several other mouse models, such as the Ts1Cje and Ms1Cje models (Sago et al., 1998, 2000) contain smaller triplicated segments of MMU16. Future studies in these segmental trisomic models will be useful to narrow the search for the particular genes responsible for the various phenotypic abnormalities observed in DS, Ts16, and Ts65Dn (0lson et al., 2004). App, Amyloid precursor protein; GRIK1, kainate selective glutamate receptor 5; SOD1, superoxide dismutase; OLIG1 and OLIG2, oligodendrocyte lineage transcription factors 1 and 2; SIM2, single minded 2; DYRK1A, dual-specificity tyrosine-regulated kinase $1 A ; E T S 2, E-26$ avian leukemia oncogene $2,3^{\prime}$ domain; Mx1, myxovirus resistance 1; Tmprss2, transmembrane protease serine 2; Zfp295, zinc finger protein 295 .

CGGGCACTGCTCAA-BHQ2a-3' (Operon). FAM and Texas Red are fluorescent reporters, and BHQ1a and 2a are dark nonfluorescent quenchers. The multiplexed PCR was set up as follows: $25 \mu$ l of Platinum qPCR Supermix UDG (Invitrogen, Carlsbad, CA), $0.5 \mu$ l of each primer $(1.5 \mu \mathrm{M}), 1.5 \mu \mathrm{l}$ of each probe $(200 \mathrm{nM})$, and $20 \mu \mathrm{l}$ of diluted template DNA $(4 \mathrm{ng} / \mu \mathrm{l})$. The reaction was performed at $50^{\circ} \mathrm{C}$ for $2 \mathrm{~min}, 95^{\circ} \mathrm{C}$ for $5 \mathrm{~min}$, followed by 42 cycles of $95^{\circ} \mathrm{C}$ for $15 \mathrm{~s}$ and $60^{\circ} \mathrm{C}$ for $40 \mathrm{~s}$ on an iCycler (Bio-Rad, Hercules, CA) with a 96-well format. For each sample, triplicate reactions were performed.

\section{Fluorescent in situ hybridization}

Interphase fluorescent in situ hybridization (FISH) with a mouse chromosome 16 specific probe (targeting part of DS critical region) distin- 
guished Ts65Dn mice from their euploid littermates using cells obtained from a drop of tail blood. Briefly, slides with interphase nuclei were prepared and hybridized as described previously (Lee et al., 1990). The mouse genomic DNA BAC clone 480C6 was obtained from the Research Genetics CITB-CJ7-B mouse BAC library (Research Genetics, Huntsville, AL) and labeled with biotin-dUTP or digoxigenin-dUTP (Boehringer Mannheim, Indianapolis, IN) in a nick-translation reaction (Tonon et al., 2000). 4',6' -Diamidino-2-phenylindole (DAPI) counterstain was used to identify nuclei. Images were taken using a $100 \times$ objective on a BX40 Olympus (Center Valley, PA) microscope in conjunction with an Improvision Orbit (Improvision, Lexington, MA) camera and acquisition system. The results illustrated in Figure 1 show an example of labeled nuclei from a Ts65Dn and euploid littermate pair.

\section{Gross measurements of embryos}

The crown rump (CR) length of each fetus was measured immediately after removal from the placenta. The images of the fixed brain were captured before dehydration on a Zeiss (Thornwood, NY) Stereo Lumar microscope. The maximum rostrocaudal and mediolateral lengths of each telencephalon were measured using Axiovision software (Zeiss) after dissection from the calvarium.

\section{Tissue sectioning and histology}

Coronal sections $(5 \mu \mathrm{m})$ from paraffin-embedded Ts65Dn and euploid littermate brains were mounted on Superfrost Plus slides (Fisher Scientific). The sections were deparaffinized with Citrisolv for $15 \mathrm{~min}$ and rehydrated through a series of descending ethanol concentrations. One in every 10 sections was stained with $0.1 \%$ cresyl violet, dehydrated, and coverslipped in Permount (Fisher Scientific).

\section{Thickness of cortical and hippocampal layers and cell density measurements}

The thickness of the cortical and hippocampal layers was measured at the level of the dorsal hippocampus (future sensorimotor cortex) (Haydar et al., 1996). This level corresponds to E13/E14 plate 5 in the work by Jacobowitz and Abbott (1998). To discriminate the different layers of fetal cortex, we used the term ventricular/subventricular zone (VZ/SVZ) to identify the area encompassing these two proliferative zones as extending from the surface of the lateral ventricle to the outermost abventricular mitotic figure. After E13.5, subplate-cortical plate (SP/CP) refers to the area bounded by the large, pale SP cells and the border between the $\mathrm{CP}$ and the marginal layer. The area between the SVZ and SP is referred to as the intermediate zone (IZ). Mitotic cells were counted in the SVZ (i.e., all abventricular mitotic figures up to the SP) of E14.5, E15.5, and E16.5 brains in the same region of each section as in the cortical thickness measurements.

Cell density measurements at E18.5 were made on $5 \mu \mathrm{m}$ coronal sections stained with $0.1 \%$ cresyl violet. All cortical layers, including VZ/ SVZ, IZ, SP, and CP, were measured. All cresyl violet-stained nuclei were counted, excluding the endothelial cells located adjacent to blood vessels. Cell counts were made on a fixed area of $50 \times 50 \mu \mathrm{m}$ and at a consistent position on the dorsal pallium for all the sections from Ts65Dn animals and their littermate controls. The cortical area in which cells were counted is demarcated by the rectangle in Figure $3 A$. The distances from the ventricular lining for the lower boundary of the counting box were 50 $\mu \mathrm{m}$ for VZ/SVZ cells, $100 \mu \mathrm{m}$ for the IZ cells, $250 \mu \mathrm{m}$ for the SP cells, and $400 \mu \mathrm{m}$ for the CP cells. Cell density measurements were also made on 20 $\mu \mathrm{m}$ coronal sections from postnatal day 8 (P8) pups using propidium iodide, a fluorescent nucleic acid dye. Cell counts were performed on a fixed area ( $500 \mu \mathrm{m}$ width by $150 \mu \mathrm{m}$ height) at each optical section for all the different layers of the cortex viz. layers II-III, IV, V, and VI. The layers of P8 neocortex were discriminated using the layer markers, Brn1 (layers I-III), ER81 (layer V), and Foxp2 (layer VI). Again, all measurements were made at the level of the sensorimotor cortex.

\section{Immunohistochemistry}

5-Iodo-2'-deoxyuridine (IdU) and/or 5-bromo-2'-deoxyuridine (BrdU) immunodetection was as follows: After a 5 min wash with $1 \mathrm{~m}$ PBS, frozen sections were treated with $0.1 \%$ trypsin (Sigma, St. Louis, $\mathrm{MO}$ ) in $0.1 \mathrm{~m}$ Tris buffer containing $0.1 \%$ calcium chloride for $5 \mathrm{~min}$ at $37^{\circ} \mathrm{C}$ followed by another $2 \mathrm{~min}$ wash with PBS. The sections were then treated with $2 \mathrm{~N} \mathrm{HCl}$ for $30 \mathrm{~min}$ at room temperature, rinsed in PBS for 2 min, and incubated with 5\% normal goat serum in PBS for $30 \mathrm{~min}$. The sections were incubated with mouse anti-BrdU (1:100; BD Biosciences, Franklin Lakes, NJ) (binds to both IdU and BrdU) and rat anti-BrdU (1:100; Abcam, Cambridge, MA) (binds to only BrdU) overnight at $4^{\circ} \mathrm{C}$. Alexa Fluor 488 goat anti-mouse IgG and Alexa Fluor 568 goat anti-rat $\operatorname{IgG}(1: 200$; Invitrogen, Carlsbad, CA) secondary antibodies were applied for $1 \mathrm{~h}$ at room temperature. The sections were then rinsed and mounted with Vectashield (Vector Laboratories, Burlingame, CA) with DAPI (nuclear label). Images were taken on an LSM510 Meta confocal microscope (Zeiss). IdU- and BrdU-labeled cells were counted in a $150 \mu \mathrm{m} \times 150$ $\mu \mathrm{m}$ frame in $15-\mu \mathrm{m}$-thick $z$-stack images ( $1 \mu \mathrm{m}$ steps) using Zeiss LSM software.

For simultaneous detection of Ki67 and BrdU, sections were incubated with rabbit anti-Ki67 antibody (1:500; Novacastra, Norwell, MA) overnight at $4^{\circ} \mathrm{C}$. RITC-conjugated goat anti-rabbit IgG (1:200; Jackson ImmunoResearch, West Grove, PA) was used as the secondary antibody for $1 \mathrm{~h}$ at room temperature. After two rinses in PBS, the sections were postfixed with $4 \%$ paraformaldehyde for $1 \mathrm{~h}$ at $4^{\circ} \mathrm{C}$. BrdU immunolabeling was then performed on Ki67-stained sections as described above.

Cumulative BrdU labeling was visualized by staining the paraffin sections with mouse anti-BrdU antibody. All the steps were performed at room temperature. The sections were deparaffinized, rehydrated, and treated with trypsin and $\mathrm{HCl}$ as described above. After $\mathrm{HCl}$ treatment, the sections were incubated with $0.3 \%$ hydrogen peroxide in methanol for 30 min. The sections were then incubated with normal horse serum followed by mouse anti-BrdU antibody (1:100) for $1 \mathrm{~h}$. Biotinylated horse anti-mouse IgG (1:200; Vector Laboratories) was used as secondary antibody for $45 \mathrm{~min}$. ABC reagent was added according to the manufacturer's instruction (Vector Laboratories) and 3,3'-diaminobenzidine (DAB) reaction was performed with SigmaFast tablets (Sigma). Brightfield images were taken on Olympus microscope and total and BrdUlabeled cells were counted in an area of $100 \mu \mathrm{m}$ width by $100 \mu \mathrm{m}$ height from the line of the lateral ventricle.

Intermediate progenitor cells were stained in paraffin sections using rabbit anti-T-Brain2 antibody (Tbr2) (1:500; Chemicon, Temecula, CA). The deparaffinized and dehydrated sections were permeabilized with methanol at $-20^{\circ} \mathrm{C}$ for $20 \mathrm{~min}$. The slides were boiled with $0.1 \mathrm{M}$ sodium citrate buffer, $\mathrm{pH}$ 6.0, for $10 \mathrm{~min}$ for antigen unmasking followed by treatment with $0.3 \%$ hydrogen peroxide in methanol for $30 \mathrm{~min}$. The sections were incubated with normal goat serum for $30 \mathrm{~min}$, and then with the primary antibody overnight at $4^{\circ} \mathrm{C}$. Biotinylated goat anti-rabbit IgG (1:200; Vector Laboratories) was used as secondary antibody and the sections were exposed for $45 \mathrm{~min}$. $\mathrm{ABC}$ reagent was added according to the manufacturer's instructions and the DAB reaction was performed also according to the manufacturer's instructions with SigmaFast tablets. Bright-field images were taken on an Olympus microscope. Tbr ${ }^{+}$cells in the neocortex were counted in an area of $100 \mu \mathrm{m}$ width by $200 \mu \mathrm{m}$ height in the dorsal medial neocortical wall at the level of sensorimotor cortex.

Presynaptic and postsynaptic proteins were visualized by staining 20 $\mu \mathrm{m}$ frozen brain sections from P8 pups with anti-mouse synaptophysin (SY38; 1:1000; Chemicon) and anti-rabbit postsynaptic density protein 95 (PSD95) (1:1000; Abcam), respectively. The secondary antibodies used were FITC-conjugated goat anti-mouse IgG (1:200; Jackson ImmunoResearch) and RITC-conjugated goat anti-rabbit (1:200; Jackson ImmunoResearch).

Staining for the layer markers was performed on $20 \mu \mathrm{m}$ frozen brain sections from P8 pups with anti-goat Brn1 (1:100; Santa Cruz Biotechnology, Santa Cruz, CA), anti-rabbit ER81 (1:10,000; Chemicon), and anti-goat Foxp2 (1:100; Santa Cruz Biotechnology). The secondary antibodies used were Alexa Fluor 488 and Alexa Fluor 546 donkey anti-goat or donkey anti-rabbit (1:200; Invitrogen).

\section{In vivo neurogenesis assay}

Pregnant Ts65Dn females at E13.5 were injected once with BrdU (50 $\mu \mathrm{g}$ per gram body weight, i.p.) and killed $24 \mathrm{~h}(n=3)$ or $48 \mathrm{~h}(n=2)$ after injection. Twenty-micrometer coronal sections of the frozen heads were 
mounted on Superfrost Plus slides and stained for BrdU. $Z$-stacks ( $1 \mu \mathrm{m}$ steps) were taken on a confocal microscope (Zeiss LSM 510 Meta) and heavily BrdU-labeled cells were counted for each layer (VZ/SVZ, IZ, and CP/SP) of the cortex. We considered the heavily labeled cells (with $>70 \%$ of the nucleus labeled with BrdU) (see Fig. 6A) in the IZ and SP/CP to represent the neurons that had exited the cell cycle just after the BrdU injection. In addition, cell cycle exit was also examined by double labeling the $24 \mathrm{~h} \mathrm{BrdU}$-exposed cells with Ki67 according to the method of Chenn and Walsh (2002). To determine the fraction of cells exiting cell cycle, $50 \mathrm{BrdU}^{+}$cells were counted from randomly chosen field of view in either the VZ/SVZ, the IZ, or the SP/CP, and then Ki67 expression was determined for those cells. BrdU ${ }^{+} \mathrm{Ki} 67^{-}$cells were identified as cells leaving the cell cycle. Results are provided for VZ, SVZ/IZ, and CP/SP.

\section{Cell cycle analyses}

Duration of S-phase (Ts). S-phase duration was determined by a doublelabeling paradigm (Martynoga et al., 2005) in which an intraperitoneal injection of IdU (Sigma; $50 \mu \mathrm{g}$ per gram body weight) was followed $1.5 \mathrm{~h}$ later by another intraperitoneal injection of BrdU (Sigma; $50 \mu \mathrm{g}$ per gram body weight) to timed pregnant Ts65Dn females. Thirty minutes later, the mother was killed and the fetuses were processed for IdU and BrdU immunohistochemistry (as above). $T_{\mathrm{s}}$ was calculated using the following model: cells in the initial IdU-labeled cohort that leave S-phase during the interval between IdU and $\operatorname{BrdU}\left(T_{i}=1.5 \mathrm{~h}\right)$ are labeled with IdU but not BrdU and are designated the leaving fraction $\left(L_{\text {cells }}\right)$. The proportion of cells labeled with BrdU is designated $S_{\text {cells. }}$. The length of S-phase $\left(T_{\mathrm{s}}\right)$ was calculated using the following formula: $T_{\mathrm{s}}=1.5 \times$ $S_{\text {cells }} / L_{\text {cells }}$.

Duration of cell cycle $\left(\mathrm{T}_{c}\right)$ and growth fraction. A cumulative BrdU labeling protocol was followed to determine (1) the growth fraction (i.e., the proportion of cells that comprise the proliferating population), (2) $T_{c}$, the length of the cell cycle, and (3) the time to reach the growth fraction $\left(T_{\mathrm{c}}-T_{\mathrm{s}}\right)$ (Nowakowski et al., 1989; Takahashi et al., 1995). Pregnant Ts65Dn females were injected with $\mathrm{BrdU}$ ( $50 \mu \mathrm{g}$ per gram body weight, i.p.) every $2 \mathrm{~h}$ with survival times of $2,6,10,14,18$, and $24 \mathrm{~h}(n=$ 3-6 for each time point per genotype). The last injection was given $2 \mathrm{~h}$ before killing. The labeling index, or fraction of cells labeled with BrdU, was determined at each time point using immunohistochemistry. All labeling experiments were started at 7:00 A.M.

\section{Western blot analysis}

For Western blot analysis of SY38 and PSD95, proteins from cortex and hippocampus of $\mathrm{P} 8$ pups were obtained by tissue homogenization in RIPA buffer (50 mu Tris-HCl, pH 7.4, $0.9 \% \mathrm{NaCl}, 1 \% \mathrm{NP}-40$, and $0.25 \%$ sodium deoxycholate). Protein concentration was determined according to manufacturer's instruction using BCA Protein Assay kit (Pierce, Rockford, IL). Fifteen micrograms of protein homogenate was loaded per well for electrophoresis after which the proteins were transferred to polyvinylidene difluoride membranes and blocked overnight at $4^{\circ} \mathrm{C}$ with $5 \%$ milk. The blots were incubated for $1.5 \mathrm{~h}$ at room temperature with one of the following primary antibodies: anti-mouse synaptophysin (1:1000; Chemicon), anti-rabbit PSD95 (1:1000; Abcam), and anti-mouse actin (1:20,000; Chemicon). After washing, blots were incubated for $1 \mathrm{~h}$ with HRP-conjugated secondary antibodies (1:10,000; Chemicon). Blots were developed by chemiluminescence using SuperSignal kit (Pierce). Quantification was done by band densitometry in the linear range using Scion Image software.

\section{Image analysis}

The analysis of SY38 and PSD95 immunoreactivity was performed on confocal $z$-stacks. The numbers of synaptic puncta were counted in a $100 \times 100 \times 15 \mu \mathrm{m}$ volume $(X, Y, Z$ planes $)$ using Volocity software (Improvision). The regions examined included stratum lucidum of CA3,
B

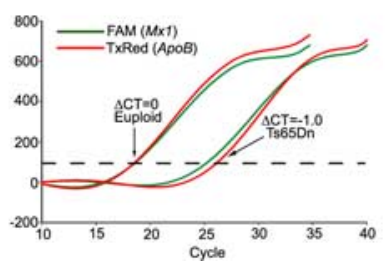

C

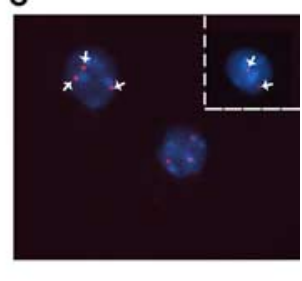

Figure 2. A quantitative PCR method for Ts65Dn genotyping. Our qPCR methods were modified from a previous report by Liu et al. (2003). A, qPCR with App as the target gene. For the euploid animals, the cycle threshold (CT) is exactly same for FAM (green) Аров for Ts65Dn ranges from -1.0 to -1.2 . C, The Down syndrome critical region (DSCR) of MMU16 detected by FISH in interphase nuclei appears as a red punctuate spot, and nuclear DAPI staining is blue. Ts65Dn nuclei are characterized by the stratum oriens of CA1 of the hippocampus, and layers II-III, IV, V, and VI of the neocortex. The average diameter of the immunolabeled puncta was measured in LSM Image Examiner software, and the object size was restricted to $4 \mu \mathrm{m}^{3}$ accordingly to select synaptic puncta. Cortical images of SY $38^{+}$and PSD95 ${ }^{+}$puncta were thresholded to select objects displaying intensity levels 3.09 and 4.87 SDs above the mean, respectively. Hippocampal images of SY38 ${ }^{+}$and $\mathrm{PSD} 95^{+}$puncta were thresholded to levels 3.81 and 6.89 SDs above the mean, respectively. The total number of such objects was counted within each image volume. Although different intensity thresholds were determined for SY38- and PSD95-stained tissue, identical image analysis settings were used for each antibody experiment between euploid and Ts65Dn littermate samples.

\section{Statistical analyses}

Comparisons of mean differences between groups (Ts65Dn vs euploid control) in brain weights, lengths, and thicknesses were based on ANOVA using the software STATA 9.1. In addition to group, each ANOVA model included effects of embryonic day and the cross product of embryonic day and group to reflect different group effects on different embryonic days. The cross product was only retained in the model if the effect was statistically significant. When evaluating differences at each embryonic day, Bonferroni's corrections (Korn and Graubard, 1990) were applied to increase the critical value needed for statistical significance to avoid false discoveries because of multiple comparisons. The rest of the comparisons were done by Student's $t$ test.

\section{Results}

\section{Validation of qPCR genotyping with fluorescent in situ hybridization}

Low fertility of the females and sterility of the males are major hurdles for developing a Ts65Dn breeding colony; most Ts65Dn studies have therefore been conducted on postnatal or adult animals. Another major challenge for managing a colony of Ts65Dn mice is the time and expense of genotyping these animals. Karyotyping and FISH on cultured lymphocytes or tail fibroblasts (Davisson and Akeson, 1987; Strovel et al., 1999) have been the most commonly used methods, but these procedures are technically demanding and lengthy and require lymphoblast culturing, which is difficult on embryonic or neonatal tissue. Previously, Liu et al. (2003) described a qPCR method to distinguish Ts65Dn animals from their euploid littermates. In this method, TaqManbased probes for amyloid precursor protein $(A p p)$ and myxovirus resistance $1(M \times 1)$ genes (both triplicated in Ts65Dn) and apolipoprotein B (ApoB) (two copies in Ts65Dn and controls) are used as reporters of tail DNA amplification. The cycle threshold (CT) of App and Mx1 is lower in Ts65Dn than in euploid controls because of the extra copy of $A p p$ and $M x 1$ on the triplicated 
A

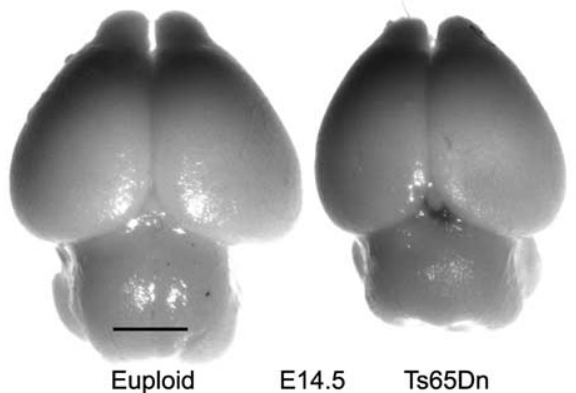

B

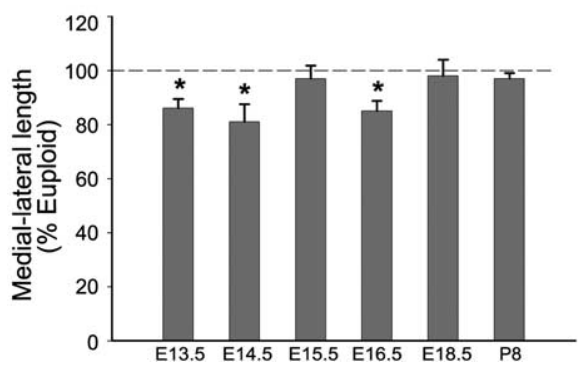

C

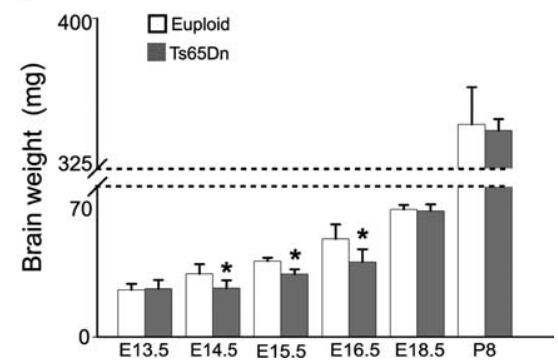

Figure 3. Gross pathology of the developing Ts65Dn brain. A, Microcephaly of the Ts65Dn forebrain at midgestation (E14.5). $\boldsymbol{B}$, The medial-lateral length of the forebrain was smaller in Ts65Dn embryos compared with euploid littermates at E13.5, E14.5, and E16.5. C, Significant reduction was found in wet brain weight in Ts65Dn embryos at E14.5, E15.5, and E16.5. Data points represent mean $\pm S D$ ( $n=6-8$ mice for each age in each genotype group). ${ }^{*} p<0.03$ by Bonferroni's correction. Scale bar, $1 \mathrm{~mm}$.

segment of MMU16. We found that the originally reported fluorescent probes used in Liu et al. exhibited significant spectral overlap when used with our hardware (iCycler; Bio-Rad) and led to many false-positive and false-negative genotypes. To prevent this spectral overlap, we modified the reporter/quencher fluorophore pairs to be FAM/Black Hole Quencher la for the App and $M x 1$ probe and Texas Red/Black Hole Quencher 2a for the $A p o B$ probe. To confirm the accuracy of our modified parameters, the results of qPCR were compared with a rapid FISH genotyping technique performed on blood from 57 adult animals (Fig. 2). In this comparative study, all of our qPCR results using probes for $A p p$ or for $M x 1$ were $100 \%$ concordant and were also confirmed by FISH, demonstrating that our qPCR probe modifications enable rapid and sensitive genotyping of the Ts65Dn colony. We therefore used this validated qPCR method using App as the target gene for genotyping the 108 pairs of Ts65Dn and euploid littermate embryos used for the primary dataset.

\section{Embryonic microcephaly in Ts65Dn}

Postnatal Ts65Dn pups are smaller and weigh less than controls (Davisson and Costa, 1999), and postnatal reductions in size have been demonstrated in the cerebellum and hippocampus (Insausti et al., 1998; Baxter et al., 2000; Olson et al., 2004; Lorenzi and Reeves, 2006; Roper et al., 2006). To determine whether this growth retardation begins prenatally, we examined embryo size during gestation. Surprisingly, for all the gestational days studied (E13.5-E18.5), no significant change was observed in the crown rump length of the Ts65Dn fetuses when compared with euploid littermate controls (supplemental Table 1, available at www. jneurosci.org as supplemental material). However, there were statistically significant differences in the medial-lateral length of the telencephalon between Ts65Dn and euploid control brains over the course of neurogenesis (ANOVA, $F_{(1,50)}=6.70 ; p<$ $0.0002)$. In particular, the medial-lateral length of the Ts65Dn telencephalon at E13.5, E14.5, and E16.5, was found to be signif- icantly smaller than controls based on differences per day of $-14,-19$, and $-15 \%$, respectively (Bonferroni corrected, $p<$ $0.001 ; n=6-8$ ) (Fig. $3 A, B$ ). There was also a statistically significant decrease in the wet brain weight of the Ts65Dn fetuses from E13.5 to E18.5 (ANOVA, $F_{(4,52)}=$ 2.67; $p<0.04)$ as well as weight deficits compared with controls at E14.5, E15.5, and E16.5 ( $-22,-17$, and $-23 \%$, respectively; Bonferroni corrected, $p<0.03$; $n=$ 6) (Fig. 3C). However, by E18.5, both the brain weight and the gross size of the Ts65Dn telencephalon were indistinguishable from controls (Fig. $3 B, C$ ). Thus, although total body size during prenatal stages appears normal, these results suggest that growth of the Ts65Dn brain is delayed early during development and that rapid expansion occurs late in gestation to offset this microcephaly before birth.

\section{Delayed expansion of Ts65Dn neocortical layers}

To more closely examine the structures affected by the microcephaly, we first conducted a morphological and histological examination of the Ts65Dn dorsomedial neocortical wall during the course of embryonic neurogenesis, from E13.5 to E18.5 (Fig. 4). In particular, we measured the thickness of all neocortical layers in the future sensorimotor cortex, including the VZ/SVZ, which contain the neural precursor cells; the IZ, which contains migrating neurons and axon tracts; and the SP/CP containing migrating and differentiating neurons. We found no consistent differences between Ts65Dn and euploid controls in VZ/SVZ thickness across all time points studied (ANOVA, $F_{(4,70)}=0.32 ; p=0.87$ ) (Fig. $4 C$ ). However, the thickness of the Ts65Dn IZ was smaller throughout the neurogenesis period (ANOVA, $F_{(4,70)}=3.18 ; p<0.02$ ). In particular, there were decreases in the thickness of the Ts65Dn IZ on E13.5, E14.5, E15.5, and E16.5 ( $-28,-33,-22$, and $-30 \%$; Bonferroni adjusted, $p<0.005$ ) but not at E18.5 (Fig. 4C). Similarly, the thickness of the SP/CP was smaller in Ts65Dn neocortex from E13.5 to E18.5 (ANOVA, $F_{(4,70)}=3.33 ; p<0.02$ ), particularly on E14.5, E15.5, and E16.5 (Bonferroni corrected, $p<0.02$ ) (Fig. $4 C$ ). Together, these changes in individual layers of the Ts65Dn neocortical wall yielded an overall decrease in pallial thickness from E13.5 to E18.5 (ANOVA, $F_{(4,70)}=4.68 ; p<0.002$ ) (Fig. $4 C$ ). Importantly, all layers of the Ts65Dn neocortical wall recover to euploid control values by E18.5. Together, these results indicate that a substantial period of early neuronal production is reduced in the Ts65Dn neocortex, but that the neocortical wall eventually recovers by E18.5. To determine whether the delay in Ts65Dn neocortical growth is attributable to higher rates of programmed cell death (PCD), we performed TUNEL and immunohistochemistry for activated caspase-3. We found very few dying cells throughout the Ts65Dn neocortex and no change from controls (data not shown). Furthermore, the thickness of the Ts65Dn VZ/ SVZ germinal zones was not different from controls throughout the neurogenesis period. The lack of appreciable PCD and the absence of a frank morphological defect in the VZ/SVZ together suggested that the delays in Ts65Dn neocortical growth may be 
attributable to more subtle proliferative abnormalities in these cells.

The significant delay in Ts65Dn neocortical expansion is transient; we measured rapid growth of the Ts65Dn neocortical wall after E16.5 such that all neocortical layers reached normal thickness by E18.5. This result is concordant with the transient microcephaly reported in Figure 3. However, despite this growth to normal thickness, there were significant reductions in cell density in the IZ $(-31 \%)$, SP $(-26 \%)$, and CP $(-18 \%)$ in the E18.5 Ts65Dn neocortex compared with littermate controls $(p<0.001 ; n=8)$ (supplemental Fig. 1A, available at www. jneurosci.org as supplemental material). Reduced cell density was also observed postnatally in the Ts65Dn neocortex at P8, specifically in layers IV, V, and VI $(-18$, -21 , and $-22 \%$, respectively; $p<0.01$; $n=4)$. Interestingly, there was no change in the density of layers II-III at P8 (supplemental Fig. $1 B$, available at www.jneurosci. org as supplemental material), suggesting a preferential deficit in the early born neurons of the deeper cortical layers, whereas cellular allocation to the upper cortical layers was unaffected. Thus, the rapid expansion of the Ts65Dn neocortical wall from E16.5 to birth does not completely ameliorate the structural abnormality caused by the early growth retardation. The Ts65Dn forebrain is hypocellular at birth and remains so up until at least P8. This provides a clear parallel with the perinatal DS neocortex, which appears histologically normal yet is markedly microcephalic.

\section{Hippocampal growth is delayed in Ts65Dn embryos}

Ts65Dn animals perform poorly on hippocampal-based behavioral tests for spatial learning memory such as the Morris water maze (Reeves et al., 1995). In addition, several studies on postnatal Ts65Dn slice cultures have demonstrated significant abnormalities in hippocampal synaptic plasticity including long-term potentiation and longterm depression (Siarey et al., 1997, 1999, 2006; Kleschevnikov et al., 2002, 2004). To determine whether these behavioral, electrophysiological, and signaling abnormalities can be explained by altered embryonic development, we measured growth of the hippocampal wall from E13.5 to E18.5, concentrating our analyses on the CA1 region as it expands radially throughout the neurogenesis period (Fig. 5). Morphometric analyses demonstrated a reduced thickness of the Ts65Dn hippocampal wall from E13.5 to E18.5 (ANOVA, $F_{(4,70)}=8.04 ; p<0.00001$ ) with particularly significant reductions at E14.5 $(-32 \% ; p<0.0001 ; n=8)$, E15.5 $(-20 \% ; p<0.0001 ; n=8)$, and E18.5 $(-8 \% ; p<0.05 ; n=8$; all Bonferroni corrected) but with no significant changes at other gestational ages. The hippocampal neuroepithelium of Ts65Dn embryos was also thinner than controls, but these changes were not
B
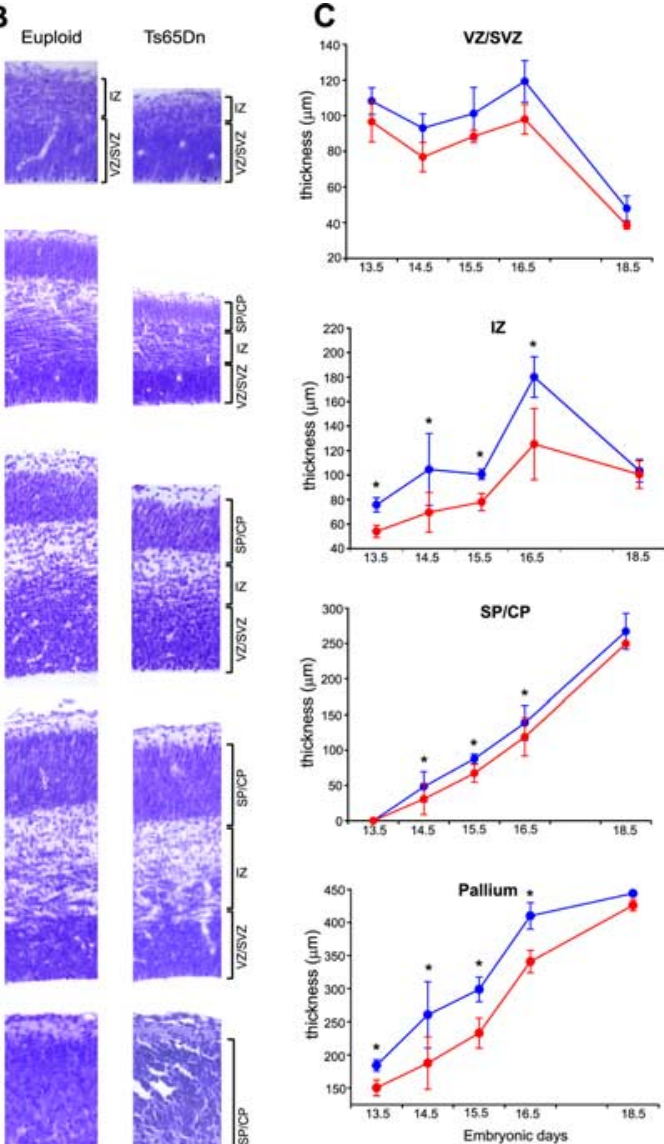

Figure 4. Histology of the embryonic Ts65Dn neocortex, a transient delay in expansion. $\boldsymbol{A}$, Nissl-stained images of coronal sections from euploid (left) and Ts65Dn (right) taken from matched sections at the level of future sensorimotor cortex. From E13.5 Dn brains are qualitatively different from the euploid brains in pallial thickness and overall size of the brain. By E18.5, the 565 D brain appears normal with respect to controls. The boxed areas in $\boldsymbol{A}$ are shown at higher magnification in $\boldsymbol{B}$ and the mediolateral position used for layer thickness measurements. $\boldsymbol{B}$, Higher magnification images of the neocortical ments (blue, euploid; red, Ts65Dn) of neocortical radial expansion demonstrate that there is a transient delay in growth of the Ts65Dn neocortical wall from E13.5 to E16.5 and that the Ts65Dn neocortex grows to normal size by E18.5. Data points represent mean \pm SD ( $n=8$ mice for each age and group). ${ }^{*} p<0.02$ by Bonferroni's correction. Scale bars: $\boldsymbol{A}, 200 \mu \mathrm{m} ; \boldsymbol{B}, 50 \mu \mathrm{m}$.

significantly different by ANOVA or $t$ test. The pyramidal cell layer, which begins to develop on E16.5, appeared to be the most affected layer in the Ts65Dn hippocampus (ANOVA, $F_{(2,42)}=11.37 ; p<$ $0.0001)$, particularly at E16.5 and E18.5 ( -24 and $-25 \%$, respectively; Bonferroni corrected, $p<0.0001 ; n=8$ ). Thus, similar to the alterations in dorsal neocortical expansion, hippocampal growth in Ts65Dn is also delayed from very early phases of its development because of reduced generation of postmitotic neurons. However, in contrast to the rapid growth of the neocortical wall from E16.5 to birth, the Ts65Dn hippocampus remains smaller during this period.

\section{Slower cell cycle in Ts65Dn neocortical and hippocampal precursor cells}

Cell cycle duration and the number of integer cell cycles during prenatal neurogenesis can influence the eventual size of the fore- 
A

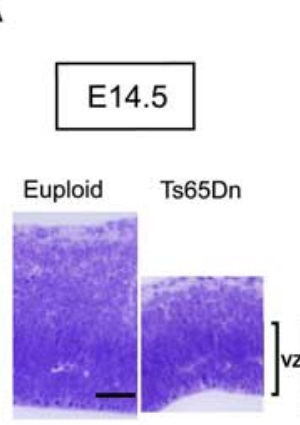

B

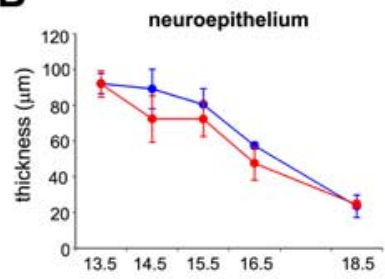

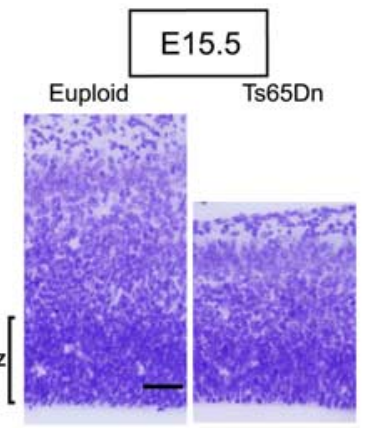

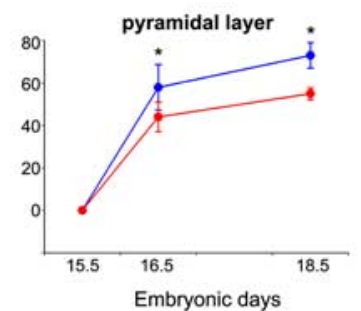

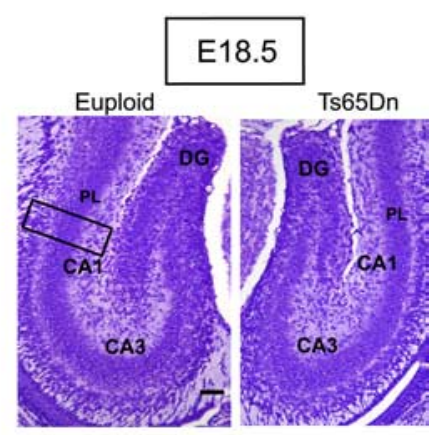

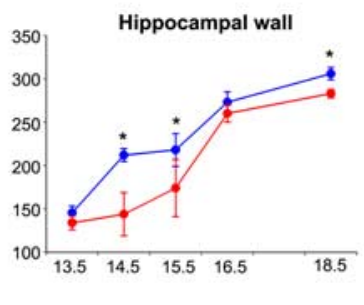

Figure 5. Histology of the embryonic Ts65Dn hippocampus. A, Nissl-stained images of the CA1 region at E14.5 and E15.5 show a decrease in the expansion of Ts65Dn hippocampal wall compared with euploids. At E18.5, dentate gyrus is hypocellular and the pyramidal layer is thinner in Ts65Dn hippocampus. B. Hippocampal layer thickness measurements (blue, euploid; red, Ts65Dn) demonstrate reduced thickness of the Ts65Dn pyramidal layer from E16.5 onward and of the pallium at E14.5, E15.5, and E18.5. PL, Pyramidal layer. Data points represent mean \pm SD ( $n=8$ mice for each age and group). ${ }^{*} p<0.05$ by Bonferroni's correction. Scale bars, $100 \mu \mathrm{m}$.

brain (Caviness et al., 1995). To determine whether altered proliferative kinetics of the VZ neural precursor cells may underlie the delays in Ts65Dn forebrain expansion, the duration of the VZ cell cycle was estimated using the cumulative BrdU-labeling procedure (Fig. 6A-D) (Takahashi et al., 1995). In addition, we separately measured the duration of S-phase using BrdU/IdU double-labeling protocol (Fig. 6F,G) (Martynoga et al., 2005). We found marked decreases in the rate of cell cycle progression in the Ts65Dn neocortical VZ (Table 1). At E13.5, the duration of S-phase $\left(T_{\mathrm{s}}\right)$ and total cell cycle $\left(T_{\mathrm{c}}\right)$ of Ts65Dn neocortical progenitors were increased by $1.2 \mathrm{~h}(p<0.01)$ and $3.2 \mathrm{~h}(p<$ 0.0001 ), respectively, relative to euploid controls. At E14.5, cell cycle progression remained slower in the Ts65Dn neocortex (Fig. $6 C$ ), where $T_{\mathrm{s}}$ (Fig. $6 G$ ) and $T_{\mathrm{c}}$ were longer than controls by $1.1 \mathrm{~h}$ $(p<0.01)$ and $2.7 \mathrm{~h}(p<0.0003)$, respectively. It is noteworthy that the growth fraction (GF) (the total percentage of proliferating VZ cells) was nearly 100\% in both euploid and Ts65Dn neocortical wall, suggesting that all Ts65Dn VZ cells are proliferating and that delayed growth of the Ts65Dn neocortical wall is not attributable to ectopic quiescent progenitor cells. In the VZ, the time to reach the GF defines $T_{\mathrm{c}}-T_{\mathrm{s}}$, or the total cell cycle minus the S-phase duration (Takahashi et al., 1995). Interestingly, the difference between Ts65Dn and euploid $T_{\mathrm{c}}-T_{\mathrm{s}}$ values steadily decreased with increasing gestational age (i.e., from $+2 \mathrm{~h}$ at E13.5 to $+0.7 \mathrm{~h}$ at E16.5) (Table 1), suggesting that the Ts65Dn cell cycle abnormality may be developmentally regulated or perhaps compensated for over the course of the neurogenesis period.

Proliferation of VZ progenitors was also abnormal in the developing CA3 region of the Ts65Dn hippocampus (Table 1). At E13.5, $T_{\mathrm{s}}$ and $T_{\mathrm{c}}$ were increased by $1.4 \mathrm{~h}(p<0.01)$ and $3.4 \mathrm{~h}$ $(p<0.0001)$, respectively, in the Ts65Dn hippocampus, compared with euploid controls. Slower cell cycle kinetics was also observed at E14.5, with $T_{\mathrm{s}}$ increased by $1.6 \mathrm{~h}(p<0.01)$ (Fig. $6 G$ ) and $T_{\mathrm{c}}$ increased by $3.1 \mathrm{~h}$ compared with controls $(p<0.0001)$ (Fig. $6 D$, Table 1). However, in contrast to neocortex, in which

the difference between Ts65Dn and euploid $T_{\mathrm{c}}-T_{\mathrm{s}}$ values continually decreases from +2 to +0.7 during the neurogenesis period, the cell cycle in the Ts65Dn hippocampal VZ remained $\sim 1.5 \mathrm{~h}$ longer than controls throughout gestation (Table 1).

\section{Reductions in prenatal neocortical neurogenesis in Ts65Dn}

In addition to the cell cycle duration, the rate of neurogenesis from VZ precursors can significantly impact the growth kinetics and eventual size of the neocortex (Caviness and Takahashi, 1995; Caviness et al., 1995; Rakic, 1995). To determine the neurogenesis rate in Ts65Dn neocortex, pregnant Ts65Dn females at E13.5 were injected with one pulse of BrdU and the embryos were killed either 24 or $48 \mathrm{~h}$ later. We used two different approaches to determine the fraction of cells exiting the cell cycle and becoming neurons. First, because repeated cell division dilutes out the BrdU label, heavily BrdU-labeled $\left(\mathrm{BrdU}^{\mathrm{HI}}\right)$ cells (Fig. 7A) found in the superficial neocortical layers were counted as the cohort of cells that had immediately exited the cell cycle after the BrdU pulse (Fig. $7 B-G$ ). Second, we determined the percentage of $\mathrm{BrdU}{ }^{+} \mathrm{Ki} 67^{-}$cells after $24 \mathrm{~h}$ of BrdU exposure because these cells represent the fraction of the BrdU-labeled cohort of cells that had left the cell cycle during the intervening $24 \mathrm{~h}$ (Fig. $7 \mathrm{H}-\mathrm{J}$ ). The total number of $\mathrm{BrdU}^{\mathrm{HI}}$ cells throughout the entire thickness of dorsal pallium was found to be significantly lower in the Ts65Dn cortex for both $24 \mathrm{~h}(-52 \% ; p<$ $0.001 ; n=3)$ and $48 \mathrm{~h}(-23 \% ; p<0.01 ; n=2)$ time periods (Fig. $7 B-G$ ), suggesting that there were fewer neurons exiting the cell cycle in Ts65Dn during these time periods. Similarly, $48 \mathrm{~h}$ after BrdU pulse (Fig. 7G), the Ts65Dn SP/CP remained deficient in BrdU $^{\mathrm{HI}}$ cells $(-47 \% ; p<0.01 ; n=2)$, demonstrating a continued impairment in neurogenesis from the Ts65Dn germinal zone. Moreover, in addition to fewer generated neurons, Figure $7 D$ illustrates that fewer $\mathrm{BrdU}^{\mathrm{HI}}$ cells were found in the Ts65Dn SP/CP $(-100 \% ; p<0.001)$ and IZ $(-63 \% ; p<0.001 ; n=3) 24 \mathrm{~h}$ after the BrdU pulse. Thus, of the cells that did exit the cell cycle, Ts65Dn neurons did not migrate as quickly as their euploid counterparts into the SP/CP. These results were further strengthened by the observation that $24 \mathrm{~h}$ after single BrdU pulse, the Ts65Dn neocortex had $47 \%$ less $\mathrm{BrdU}^{+} \mathrm{Ki}^{-}{ }^{-}$cells in the SVZ/IZ $(p<0.0002 ; n=3)$, indicating that the euploid germinal zones generate almost twice as many neurons as do the progenitors in the Ts65Dn neocortex (Fig. 7 H,I). Together, these experiments indicate that significant reductions in neurogenesis and slower neuronal migration contribute to the delayed growth of the midgestational Ts65Dn neocortical wall and to the resulting decrease in cell density found at late gestational and postnatal brain.

\section{Increased mitotic activity in the Ts65Dn neocortical SVZ}

The embryonic neocortical VZ is joined at midgestation by a secondary proliferative population in the SVZ. Recent evidence suggests that the SVZ contains a population of intermediate progenitor cells (IPCs) that undergoes neuron-generating divisions and substantially contributes to neuronal production (Noctor et 
al., 2004; Englund et al., 2005). We used immunostaining for T-brain2 (Tbr2) to identify the IPC population during brain development (Englund et al., 2005). Surprisingly, in contrast to the reduced output from the VZ, we observed an increase in the number of $\mathrm{Tbr} 2^{+}$IPCs in the Ts65Dn neocortex from E14.5 to E16.5 $\left(\right.$ ANOVA, $\left.F_{(2,12)}=4.80 ; p<0.03\right)$, particularly at E16.5 ( $+41 \%$; Bonferroni adjusted, $p<0.02 ; n=3$ ) (Fig. $8 A, B$ ). To determine whether the larger Tbr $2^{+}$population was attributable to increased SVZ proliferation, we counted the number of mitotic cells in the SVZ (Fig. 8C). We found that there is an initial paucity of SVZ mitoses in the Ts65Dn neocortical wall at E15.5 but that this lag is followed by a rapid increase (21\% over controls) in SVZ mitotic figures at E16.5 $(n=10)$ (Fig. $8 C, D)$. Specifically, whereas the mitotic index in the euploid neocortical SVZ grew from 0.73 to $0.79 \%$ from E15.5 to E16.5, the percentage of mitotic SVZ cells in the Ts65Dn neocortex grew from 0.58 to $0.96 \%$ during the same period. Although these differences were only borderline significant by $t$ test ( $p=0.075$ ), this bolstering of the IPC population most likely contributes to the rapid expansion of the Ts65Dn neocortical wall before birth.

\section{Synapse development is impaired in} Ts65Dn neocortex and hippocampus To determine the physiological effects of the altered course of Ts65Dn neocortical neurogenesis, we analyzed synapse formation in the neocortex and hippocampus of P8 brains using Western blot and immunofluorescence. Densitometric analyses of Western blots demonstrated that total amounts of the presynaptic protein synaptophysin (SY38) and the postsynaptic density protein-95 (PSD95) were decreased in Ts65Dn cortex (SY38, - 18\%; PSD95, $-45 \%$; $p<0.05 ; n=3$ ) (Fig. $9 A, B$ ). A reduction in synaptic protein levels was also observed in Ts65Dn hippocampus (SY38, $-17 \%$; PSD95, $-50 \%$; $p<0.05 ; n=3$ ) (Fig. 9A,B). To distinguish whether the decrease in total synaptic protein levels was attributable to reduced levels of synaptic proteins per synapse or to fewer synapses, we counted the number of synaptic puncta for both presynaptic and postsynaptic terminals in the stratum lucidum of CA3 and in the stratum oriens of CA1 of the hippocampus at $\mathrm{P} 8$. Volumetric analyses on reconstructed confocal $z$-stacks of the hippocampus uncovered fewer PSD95 ${ }^{+}$ puncta $(-63 \% ; p<0.001 ; n=5)$ in the CA3 region of the Ts65Dn hippocampus with no difference in the counts of SY3 $8^{+}$ puncta (Fig. 9C). In contrast, SY38 ${ }^{+}$and $\mathrm{PSD} 95^{+}$puncta were reduced ( -28 and $-50 \%$, respectively; $p<0.03 ; n=5$ ) in the CA1 region in Ts65Dn brain (Fig. 9C).

To look more closely at individual layers of the neocortical wall, we used immunostaining for SY38, PSD95, and layer markers followed by confocal microscopy and volumetric quantifica- tion (Fig. 9D,E). We found fewer SY $38^{+}$puncta in layers II-III, IV, V, and VI of the Ts65Dn neocortex on P8 $(-27,-21,-32$, and $-39 \%$, respectively; $p<0.009 ; n=5$ ). In addition, there were fewer PSD95 ${ }^{+}$terminals in layers IV, V, and VI of the Ts65Dn neocortex $(-39,-47$, and $-27 \%$, respectively; $p<$ $0.005 ; n=5)$. Together, these results indicate that the prenatal neurogenesis abnormalities in the Ts65Dn forebrain, caused by altered neural precursor proliferation, lead to significant changes in the postnatal onset of cortical and hippocampal synaptogenesis.

\section{Discussion}

DS is a multifaceted syndrome in which the combination of several different CNS abnormalities results in a complex neurological phenotype. It is important to identify the earliest brain abnormalities in DS because primary changes in brain formation can influence synaptic development and circuit refinement and thereby eventually impact motor function and cognition. As 
Table 1. Summary of duration of cell cycle phases for Ts65Dn and euploid forebrain precursor cells

\begin{tabular}{|c|c|c|c|c|c|c|c|c|c|}
\hline \multirow[b]{2}{*}{ Age } & \multirow[b]{2}{*}{ Genotype } & \multicolumn{4}{|c|}{ Cortex } & \multicolumn{4}{|c|}{ Hippocampus } \\
\hline & & GF & $T_{\mathrm{c}}-T_{\mathrm{s}}(\mathrm{h})$ & $T_{s}(\mathrm{~h})$ & $T_{c}(\mathrm{~h})$ & GF & $T_{\mathrm{c}}-T_{\mathrm{s}}(\mathrm{h})$ & $T_{s}(\mathrm{~h})$ & $T_{\mathrm{c}}(\mathrm{h})$ \\
\hline \multirow[t]{2}{*}{ E13.5 } & Euploid & 1 & 11.8 & $5.7 \pm 0.2$ & $17.5 \pm 0.3$ & 1 & 11.3 & $6.0 \pm 0.3$ & $17.3 \pm 0.3$ \\
\hline & Ts65Dn & 1 & 13.8 & $6.9 \pm 0.3^{*}$ & $20.7 \pm 0.5^{* *}$ & 1 & 13.2 & $7.4 \pm 0.3^{*}$ & $20.7 \pm 0.4^{* *}$ \\
\hline \multirow[t]{2}{*}{ E14.5 } & Euploid & 1 & 13.3 & $6.3 \pm 0.6$ & $19.6 \pm 0.7$ & 1 & 13.6 & $6.3 \pm 0.5$ & $19.9 \pm 0.6$ \\
\hline & Ts65Dn & 1 & 14.9 & $7.4 \pm 0.3^{*}$ & $22.3 \pm 0.4^{* *}$ & 1 & 15.1 & $7.9 \pm 0.4^{*}$ & $23.0 \pm 0.5^{* *}$ \\
\hline \multirow[t]{2}{*}{ E15.5 } & Euploid & 0.92 & 13.9 & - & - & 1 & 14.2 & - & - \\
\hline & Ts65Dn & 0.88 & 15.1 & - & - & 0.92 & 15.8 & - & - \\
\hline \multirow[t]{2}{*}{ E16.5 } & Euploid & 0.84 & 13.7 & - & - & 1 & 14.6 & - & - \\
\hline & Ts65Dn & 0.8 & 14.4 & - & - & 0.9 & 16.1 & - & - \\
\hline
\end{tabular}

$T_{\mathrm{s}}$ data represent mean $\pm \mathrm{SD}(n=3-4)$. GF, Growth fraction; $T_{\mathrm{s}^{\prime}}$ duration of $S$-phase; $T_{\mathrm{C}^{\prime}}$ duration of cell cycle; - , not determined.

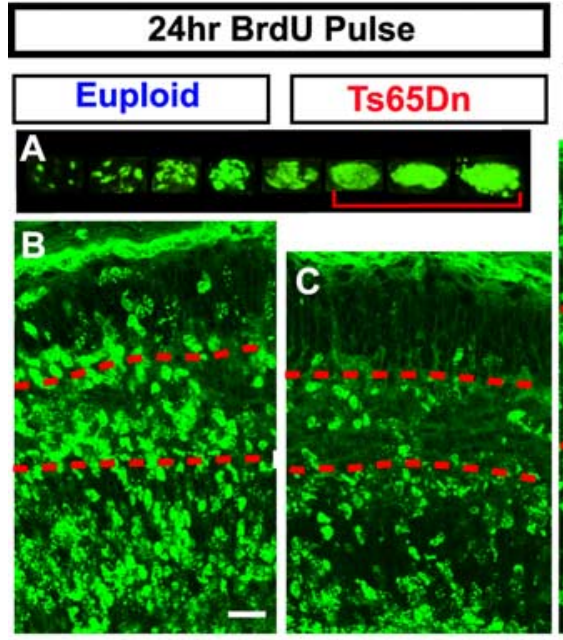

D

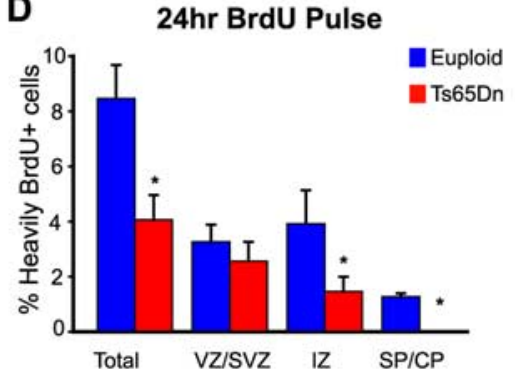

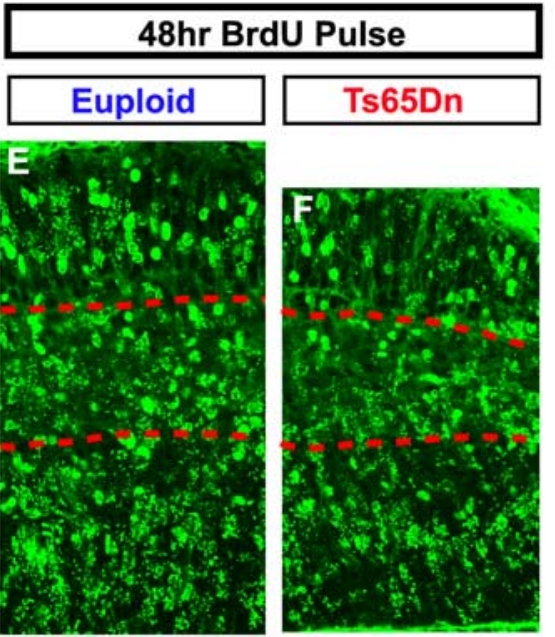

G

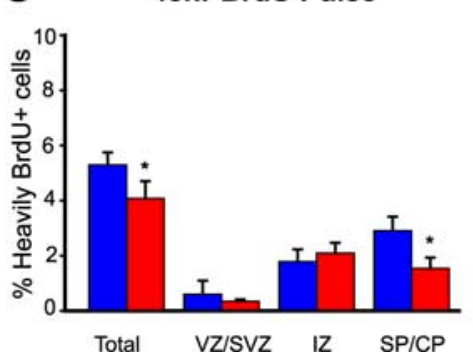

\section{4hr BrdU Pulse (Ki67 at $24 \mathrm{hrs)}$}

Euploid $T$ Ts65Dn
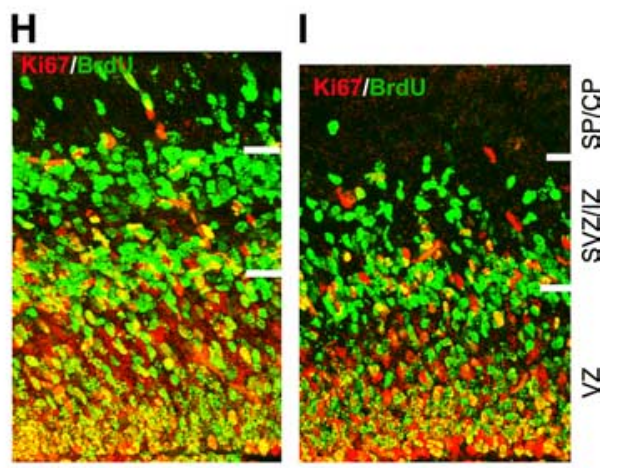

J

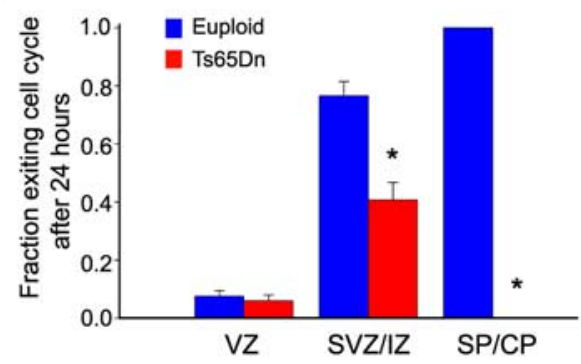

Figure 7. Reduced neurogenesis and slower neuronal migration in Ts65Dn neocortex ( $\boldsymbol{A}-\mathbf{G})$. E13.5 timed pregnant Ts65Dn females were injected (intraperitoneally) with BrdU to label a cohort of neural progenitors in S-phase and embryos were harvested 24 or $48 \mathrm{~h}$ later. The number and radial position of heavily BrdU ${ }^{+}$cells in the neocortex were measured for both time points. $\boldsymbol{A}$, Examples of the range of nuclear BrdU labeling observed. Only cells with $>70 \%$ of the nucleus stained for BrdU were scored (represented by the cells within the red bracket). Cells with less nuclear BrdU staining were considered to have gone through additional mitotic divisions and were omitted from the counts. $\boldsymbol{B}-\boldsymbol{D}$, At $_{24} \mathrm{~h}$ after injection, the number of heavily BrdU ${ }^{+}$cells in the Ts65Dn IZ and SP/CP was significantly less than that of euploid controls, suggesting that fewer cells had exited the cell cycle and differentiated into migrating neurons during this period of time. In addition, these fewer Ts65Dn neurons migrated at a slower rate; all were found only in the IZ, whereas $20 \%$ of the euploid neurons had already migrated into the SP/CP. Data points represent mean \pm SD $(n=$ 3 pairs). $\boldsymbol{E}-\mathbf{G}$, Fewer heavily BrdU-labeled neurons were also found in Ts65Dn $48 \mathrm{~h}$ after injection. Most of the newly generated neurons in Ts65Dn neocortex had migrated into the IZ, but fewer neurons were found in the SP/CP compared with euploid controls. Data points represent mean \pm SD ( $n=2$ pairs). $\boldsymbol{H}-\boldsymbol{J}$, At $24 \mathrm{~h}$ after BrdU injection, sections were stained with antibodies to Ki67 (red) and BrdU (green). The fraction of cells labeled only with BrdU (BrdU ${ }^{+} / \mathrm{Ki}^{-} 7^{-}$; no longer dividing) $24 \mathrm{~h}$ after pulse label is $47 \% \mathrm{smaller} \mathrm{in} \mathrm{Ts65Dn.} \mathrm{Data} \mathrm{points} \mathrm{represent} \mathrm{mean} \pm \mathrm{SD}(n=3$ pairs). ${ }^{*} p<0.01$ by paired $t$ test. Scale bar, $20 \mu \mathrm{m}$.

such, interventions aimed at the earliest defects will provide the highest likelihood of counteracting the postnatal neurological complications. Although brain abnormalities have been found in DS as early as midgestation, early embryonic development has not yet been characterized, leaving open the possibility that prenatal defects may contribute to the alterations in brain morphology and function. We tested this hypothesis in the Ts65Dn mouse model of DS and have now identified several abnormalities in neuronal development that occur during a specific window of early gestation. Because of breeding difficulties and reduced via- bility of Ts65Dn embryos, all previous studies have been performed on postnatal animals. Our results, which are the first comprehensive examination of Ts65Dn embryonic brain development, demonstrate that histogenesis of the Ts65Dn forebrain is severely delayed because of proliferative abnormalities in the embryonic neural precursor cells. In addition, we extended our prenatal findings to the early postnatal period. We found that the embryonic abnormalities in the Ts65Dn neocortex result in reduced neuronal density and correlate with delayed synapse formation in the cortex and hippocampus. Because of the genetic 
similarities between Ts65Dn and DS, these results strongly suggest that similar abnormalities may occur during brain development in DS.

\section{Cell proliferation abnormalities in Ts65Dn and DS development}

Many findings point to the idea that reduced cell proliferation is a common phenotype throughout the lifespan of animal models and humans with DS and that altered proliferation substantially affects the nervous system. In our studies of brain development in Ts16 and Ts65Dn embryos (Haydar et al., 1996, 2000; Cheng et al., 2004), we found that cell cycle and neurogenesis defects result in delayed embryonic corticogenesis. In addition, a recent study demonstrates altered proliferation of neuronal precursors in the hippocampus and dorsal neocortical wall in second trimester DS brain (Contestabile et al., 2007). Postnatally, the DS cerebral cortex contains less cyclin-dependent kinase activity (Bernert et al., 1996) and both DNA synthesis and doubling times are slower in DS fibroblasts (Schneider and Epstein, 1972; Kimura et al., 2005). Furthermore, in the postnatal Ts65Dn brain, a reduced mitotic index has been found in the external granule cells of the cerebellum (Roper et al., 2006), and proliferation of neural stem cells is reduced in the postnatal and adult dentate gyrus (Rueda et al., 2005; Clark et al., 2006; Contestabile et al., 2007). Thus, a neural cell proliferation phenotype is present in many cell types and CNS compartments. This proliferation defect persists after birth and likely continues to impact brain growth and function into adulthood in DS.

Several lines of evidence suggest that neural precursor dynamics are actively modulated during development of the Ts65Dn neocortex. For example, although we found that the VZ cell cycle is consistently longer than controls throughout the neurogenesis period in the Ts65Dn neocortex, the difference between Ts65Dn and euploid $T_{\mathrm{c}}$ becomes steadily smaller with increasing gestational age, suggesting that the factor(s) which lengthen $T_{\mathrm{c}}$ in the trisomic VZ are either developmentally regulated or are slowly overcome. In addition, there also appears to be compensation in the SVZ for the initial decreases in VZ neurogenesis. In particular, we found marked increases in the SVZ mitotic index and the size of the Tbr ${ }^{+}$intermediate progenitor cell population in the Ts65Dn neocortex at E16.5. This surge in neocortical proliferation occurs just before a rapid thickening of the Ts65Dn neocortical wall to control values at E18.5, and may reflect an endogenous mechanism whereby hyperproliferation in the SVZ can enhance neuronal production in response to abnormally low neurogenesis rates in the VZ. It is important to note that we measured a similar effect on the kinetics of neocortical growth during embryonic neurogenesis in the Ts16 mouse [i.e., a transient delay followed by a rapid increase in neocortical thickness (Haydar et al., 1996, 2000; Cheng et al., 2004)]. Whether this compensatory interplay between VZ and SVZ output is a general characteristic of the developing mammalian neocortex or whether this is a phenomenon particular to the trisomic brain remains to be determined. It will also be important for future
C

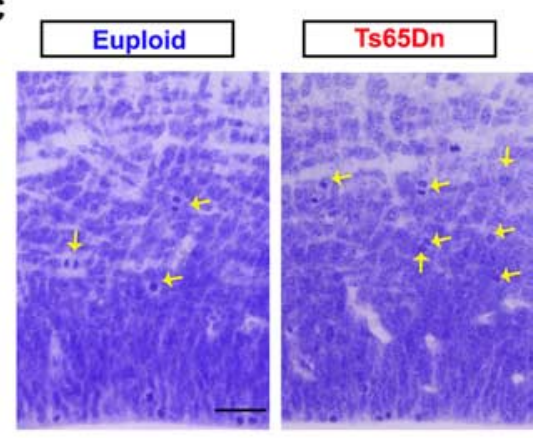

D

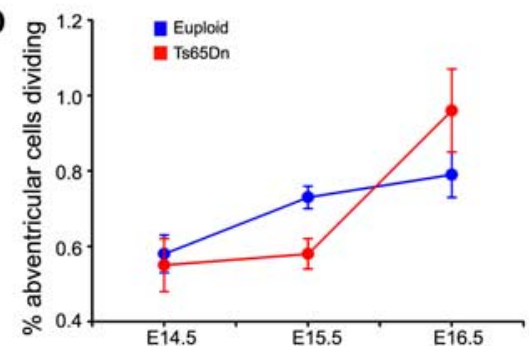

studies to determine whether the increase in Tbr ${ }^{+}$cells is attributable to more successive rounds of division in the Ts65Dn SVZ compared with controls or to increased output of IPCs from the VZ. In any case, together, the gradual lessening of the $T_{\mathrm{c}}$ abnormality and the increased number of Tbr ${ }^{+}$SVZ cells in late fetal stages are presumed to account for the rapid growth of the Ts65Dn neocortical wall just before birth.

Comparable morphometric changes have been noted in DS and Ts65Dn with respect to hippocampal development. Hippocampal volume is markedly reduced in infants and young adults with DS (Pinter et al., 2001a,b), and the dentate gyrus and pyramidal cell layers are particularly affected (Sylvester, 1983). Similarly, hippocampal hypocellularity and reduced volume of the dentate gyrus have also been reported in postnatal and adult Ts65Dn, with the earliest defect reported at P6 (Kurt et al., 2004; Rueda et al., 2005; Lorenzi and Reeves, 2006). Here, we demonstrate that hippocampal development in Ts65Dn is abnormal from very early embryonic stages. In particular, the cell cycle of the embryonic progenitors in the ammonic proliferative zone, thought to be precursors of excitatory hippocampal neurons (Altman and Bayer, 1990; Navarro-Quiroga et al., 2007), is significantly slower in Ts65Dn than in controls, and this leads to a delay in formation and synaptic development of the pyramidal cell layers. Our results therefore suggest that decreases in neurogenesis starting at E14.5 are likely to be the basis of the morphological and functional changes observed in the postnatal Ts65Dn hippocampus.

\section{Defects in synapse formation in Ts65Dn and DS forebrain}

Previous studies on adult Ts65Dn animals have demonstrated abnormal synaptic structures (Belichenko et al., 2004) and deficits of synaptic density (Kurt et al., 2004) in the hippocampus, but basic aspects of early synapse formation were not explored. We 
A

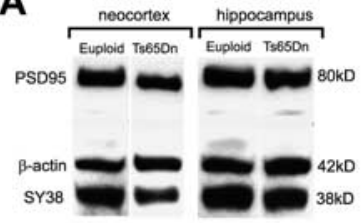

C

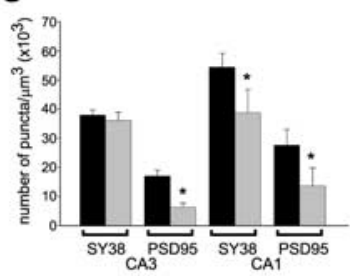

D
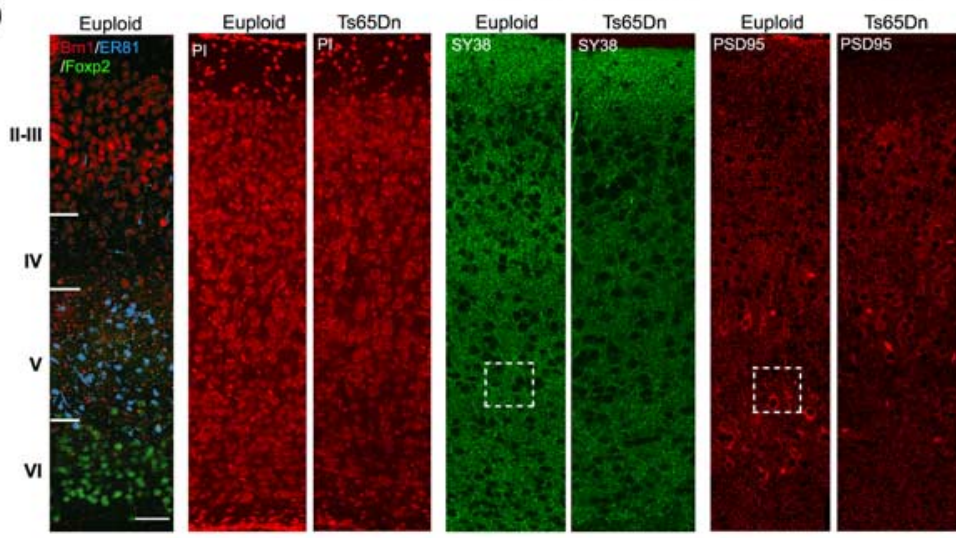

E
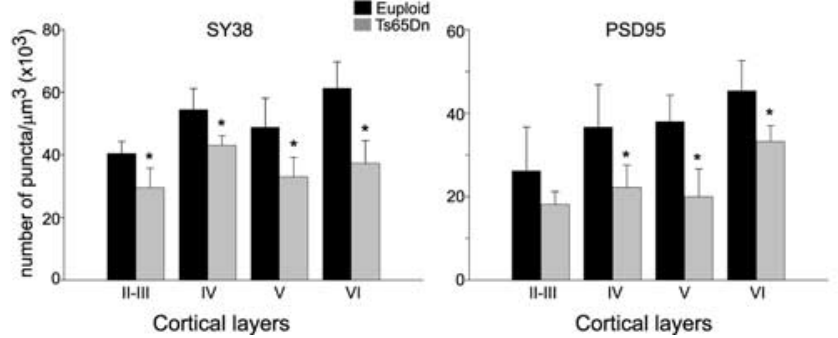

Figure 9. Reduced synaptogenesis in Ts65Dn neocortex and hippocampus. Total protein levels for synaptophysin (SY38) and postsynaptic density protein (PSD95) were measured in P8 neocortex and hippocampus. A, A representative Western blot from one Ts65Dn/euploid littermate pair. $\boldsymbol{B}$, Quantification of SY38 and PSD95 band densitometries sorted by region shows lower amounts of protein in Ts65Dn. Data points represent mean $\pm S D\left(n=3\right.$ pairs). ${ }^{*} p<0.05$ by paired $t$ test. $C$, Quantification of the number of synaptic puncta in hippocampal volume reconstructions shows fewer postsynaptic terminals in the stratum lucidum in the $C A 3$, whereas both presynaptic and postsynaptic terminals are reduced in the stratum oriens of CA1. Data points represent mean $\pm S D$ ( $n=5$ pairs). ${ }^{*} p<0.03$ by paired $t$ test. $D$, Immunofluorescence staining demonstrating the reduced intensity and smaller number of presynaptic and postsynaptic puncta in Ts65Dn cortical layers. $E$, Quantification of the number of synaptic puncta shows fewer presynaptic and postsynaptic terminals in all the layers of the Ts65Dn cortex. Data points represent mean \pm $\mathrm{SD}\left(n=5\right.$ pairs). ${ }^{*} p<0.009$ by paired $t$ test. Scale bar, $50 \mu \mathrm{m}$.

reasoned that the early brain histogenetic abnormalities in Ts65Dn lead to delays in neuronal differentiation. It is well accepted that synaptogenesis in many regions of the CNS occurs during limited time windows (Jeanmonod et al., 1981; Cooper and Steindler, 1989; Ghosh and Shatz, 1994). If these critical periods are missed because of early delays in neurogenesis, it has been hypothesized that reductions in synaptogenesis could follow, leading to long-lasting cognitive deficits (Haydar, 2005). Here, prenatal neurogenesis defects lead to reduced neuronal cell density in the Ts65Dn neocortex and hippocampus both before and just after birth, and all of these events precede substantial decreases in the amount of early postnatal synaptogenesis. Although it is possible that the postnatal defects in Ts65Dn arise from completely separate causes, it is more likely that the significant disruptions in cellular allocation and number we have measured underlie the synaptogenesis phenotype.

Our results demonstrate that neurons in the CA3 region of the $\mathrm{P} 8$ Ts65Dn hippocampus have a similar number of presynaptic terminals in comparison with the euploids and therefore likely receive normal input from the dentate gyrus (DG). However, fewer postsyn- aptic puncta in CA3 in the Ts65Dn hippocampus suggests that these neurons do not adequately respond to the DG inputs with postsynaptic specializations. This synaptic abnormality at $\mathrm{P} 8$ in CA3 may account for the fewer presynaptic and postsynaptic puncta in the CA1 region of the Ts65Dn hippocampus.

We also found substantial reductions in synapse markers in all layers of the Ts65Dn neocortex at P8. It is therefore important to note that the increased neurogenesis late in Ts65Dn gestation, which may be attributable to higher rates of SVZ proliferation, does not prevent this synaptic abnormality, although layers II-III contain an appropriate number of neurons. We believe that these results demonstrate that even transient delays in prenatal brain development can have profound effects on connectivity.

Several studies have demonstrated that the cerebral cortex and hippocampus are affected by prenatal exposures to ethanol, toluene, or sodium valproate (Miller, 1993; Gospe and Zhou, 2000; Grandjean and Landrigan, 2006; Manent et al., 2007). Common developmental defects from these toxins include microcephaly, abnormal neurogenesis and migration, altered interneuron organization, and impaired motor function. Thus, prenatal disruptions can lead directly to postnatal cognitive sequelae. Our present results on Ts65Dn forebrain development demonstrate that genetically based defects in neurogenesis and migration can also preferentially target hippocampal and cortical development and lead to postnatal deficits in synapse formation and cognitive function.

Brain development occurs via highly regulated stages of proliferation, migration, differentiation, and synaptogenesis. Each stage must be successfully and expeditiously completed before onset of the next stage to result in proper development and cognitive function. The significant abnormalities in cell density and synapse formation identified in the Ts65Dn neocortex and hippocampus can now be used as biological endpoints to test the efficacy of targeted manipulations of precursor proliferation in the Ts65Dn forebrain. Together, the present results on Ts65Dn forebrain development clearly indicate that similar changes in early embryonic development may predispose DS embryos to cognitive, motor, and sensory disabilities after birth.

\section{References}

Altman J, Bayer SA (1990) Mosaic organization of the hippocampal neuroepithelium and the multiple germinal sources of dentate granule cells J Comp Neurol 301:325-342.

Baxter LL, Moran TH, Richtsmeier JT, Troncoso J, Reeves RH (2000) Discovery and genetic localization of Down syndrome cerebellar phenotypes using the Ts65Dn mouse. Hum Mol Genet 9:195-202.

Becker LE, Armstrong DL, Chan F (1986) Dendritic atrophy in children with Down's syndrome. Ann Neurol 20:520-526. 
Belichenko PV, Masliah E, Kleschevnikov AM, Villar AJ, Epstein CJ, Salehi A, Mobley WC (2004) Synaptic structural abnormalities in the Ts65Dn mouse model of down syndrome. J Comp Neurol 480:281-298.

Benavides-Piccione R, Ballesteros-Yanez I, de Lagran MM, Elston G, Estivill X, Fillat C, Defelipe J, Dierssen M (2004) On dendrites in Down syndrome and DS murine models: a spiny way to learn. Prog Neurobiol 74:111-126.

Bernert G, Nemethova M, Herrera-Marschitz M, Cairns N, Lubec G (1996) Decreased cyclin dependent kinase in brain of patients with Down syndrome. Neurosci Lett 216:68-70.

Canfield MA, Honein MA, Yuskiv N, Xing J, Mai CT, Collins JS, Devine O, Petrini J, Ramadhani TA, Hobbs CA, Kirby RS (2006) National estimates and race/ethnic-specific variation of selected birth defects in the United States, 1999-2001. Birth Defects Res A Clin Mol Teratol 76:747-756.

Caviness Jr VS, Takahashi T (1995) Proliferative events in the cerebral ventricular zone. Brain Dev 17:159-163.

Caviness Jr VS, Takahashi T, Nowakowski RS (1995) Numbers, time and neocortical neuronogenesis: a general developmental and evolutionary model. Trends Neurosci 18:379-383.

Chapman RS, Hesketh LJ (2000) Behavioral phenotype of individuals with Down syndrome. Ment Retard Dev Disabil Res Rev 6:84-95.

Cheng A, Haydar TF, Yarowsky PJ, Krueger BK (2004) Concurrent generation of subplate and cortical plate neurons in developing trisomy 16 mouse cortex. Dev Neurosci 26:255-265.

Chenn A, Walsh CA (2002) Regulation of cerebral cortical size by control of cell cycle exit in neural precursors. Science 297:365-369.

Clark S, Schwalbe J, Stasko MR, Yarowsky PJ, Costa AC (2006) Fluoxetine rescues deficient neurogenesis in hippocampus of the Ts65Dn mouse model for Down syndrome. Exp Neurol 200:256-261.

Contestabile A, Fila T, Ceccarelli C, Bonasoni P, Bonapace L, Santini D, Bartesaghi R, Ciani E (2007) Cell cycle alteration and decreased cell proliferation in the hippocampal dentate gyrus and in the neocortical germinal matrix of fetuses with down syndrome and in Ts65Dn mice. Hippocampus 17:665-678.

Cooper NG, Steindler DA (1989) Critical period-dependent alterations of the transient body image in the rodent cerebral cortex. Brain Res 489:167-176.

Davisson MT, Akeson EC (1987) An improved method for preparing G-banded chromosomes from mouse peripheral blood. Cytogenet Cell Genet 45:70-74.

Davisson MT, Costa AC (1999) Mouse models of Down syndrome. New York: Plenum.

Dierssen M, Fillat C, Crnic L, Arbones M, Florez J, Estivill X (2001) Murine models for Down syndrome. Physiol Behav 73:859-871.

Englund C, Fink A, Lau C, Pham D, Daza RA, Bulfone A, Kowalczyk T, Hevner RF (2005) Pax6, Tbr2, and Tbr1 are expressed sequentially by radial glia, intermediate progenitor cells, and postmitotic neurons in developing neocortex. J Neurosci 25:247-251.

Galdzicki Z, Siarey RJ (2003) Understanding mental retardation in Down syndrome using trisomy 16 mouse models. Genes Brain Behav 2:167-178.

Gardiner K, Fortna A, Bechtel L, Davisson MT (2003) Mouse models of Down syndrome: how useful can they be? Comparison of the gene content of human chromosome 21 with orthologous mouse genomic regions. Gene 318:137-147.

Ghosh A, Shatz CJ (1994) Segregation of geniculocortical afferents during the critical period: a role for subplate neurons. J Neurosci 14:3862-3880.

Golden J, Hyman B (1994) Development of the superior temporal neocortex is anomalous in trisomy 21. J Neuropathol Exp Neurol 53:513-520.

Gospe Jr SM, Zhou SS (2000) Prenatal exposure to toluene results in abnormal neurogenesis and migration in rat somatosensory cortex. Pediatr Res 47:362-368.

Grandjean P, Landrigan PJ (2006) Developmental neurotoxicity of industrial chemicals. Lancet 368:2167-2178.

Haydar TF (2005) Advanced microscopic imaging methods to investigate cortical development and the etiology of mental retardation. Ment Retard Dev Disabil Res Rev 11:303-316.

Haydar TF, Blue ME, Molliver ME, Krueger BK, Yarowsky PJ (1996) Consequences of trisomy 16 for mouse brain development: corticogenesis in a model of Down syndrome. J Neurosci 16:6175-6182.

Haydar TF, Nowakowski RS, Yarowsky PJ, Krueger BK (2000) Role of founder cell deficit and delayed neuronogenesis in microencephaly of the trisomy 16 mouse. J Neurosci 20:4156-4164.

Insausti AM, Megias M, Crespo D, Cruz-Orive LM, Dierssen M, Vallina IF, Insausti R, Florez J (1998) Hippocampal volume and neuronal number in Ts65Dn mice: a murine model of Down syndrome. Neurosci Lett 253:175-178.

Jacobowitz DM, Abbott LC (1998) Chemoarchitectonic atlas of the developing mouse brain. Boca Raton, FL: CRC.

Jeanmonod D, Rice FL, Van der Loos H (1981) Mouse somatosensory cortex: alterations in the barrelfield following receptor injury at different early postnatal ages. Neuroscience 6:1503-1535.

Jernigan TL, Bellugi U (1990) Anomalous brain morphology on magnetic resonance images in Williams syndrome and Down syndrome. Arch Neurol 47:529-533.

Kimura M, Cao X, Skurnick J, Cody M, Soteropoulos P, Aviv A (2005) Proliferation dynamics in cultured skin fibroblasts from Down syndrome subjects. Free Radic Biol Med 39:374-380.

Kleschevnikov AM, Belichenko PV, Basu SB, Epstein CJ, Villar AJ, Malenka RC, Mobley WC (2002) Increased inhibition as a cause of suppressed plasticity in dentate gyrus of Ts65Dn mice, an animal model of Down syndrome. Soc Neurosci Abstr 28:751.754.

Kleschevnikov AM, Belichenko PV, Villar AJ, Epstein CJ, Malenka RC, Mobley WC (2004) Hippocampal long-term potentiation suppressed by increased inhibition in the Ts65Dn mouse, a genetic model of Down syndrome. J Neurosci 24:8153-8160.

Kola I, Hertzog PJ (1998) Down syndrome and mouse models. Curr Opin Genet Dev 8:316-321.

Korn EL, Graubard BI (1990) Simultaneous testing of regression coefficients with complex survey data: use of Bonferroni $t$ statistics. Am Stat 44:270-276.

Kurt MA, Kafa MI, Dierssen M, Davies DC (2004) Deficits of neuronal density in CA1 and synaptic density in the dentate gyrus, CA3 and CA1, in a mouse model of Down syndrome. Brain Res 1022:101-109.

Lee JJ, Warburton D, Robertson EJ (1990) Cytogenetic methods for the mouse: preparation of chromosomes, karyotyping, and in situ hybridization. Anal Biochem 189:1-17.

Liu DP, Schmidt C, Billings T, Davisson MT (2003) Quantitative PCR genotyping assay for the Ts65Dn mouse model of Down syndrome. Biotechniques $35: 1170-1174,1176,1178$.

Lorenzi HA, Reeves RH (2006) Hippocampal hypocellularity in the Ts65Dn mouse originates early in development. Brain Res 1104:153-159.

Manent JB, Jorquera I, Mazzucchelli I, Depaulis A, Perucca E, Ben-Ari Y, Represa A (2007) Fetal exposure to GABA-acting antiepileptic drugs generates hippocampal and cortical dysplasias. Epilepsia 48:684-693.

Marin-Padilla M (1976) Pyramidal cell abnormalities in the motor cortex of a child with Down's syndrome. A Golgi study. J Comp Neurol 167:63-81.

Martynoga B, Morrison H, Price DJ, Mason JO (2005) Foxg1 is required for specification of ventral telencephalon and region-specific regulation of dorsal telencephalic precursor proliferation and apoptosis. Dev Biol 283:113-127.

Miller MW (1993) Migration of cortical neurons is altered by gestational exposure to ethanol. Alcohol Clin Exp Res 17:304-314.

Navarro-Quiroga I, Chittajallu R, Gallo V, Haydar TF (2007) Long-term, selective gene expression in developing and adult hippocampal pyramidal neurons using focal in utero electroporation. J Neurosci 27:5007-5011.

Noctor SC, Martinez-Cerdeno V, Ivic L, Kriegstein AR (2004) Cortical neurons arise in symmetric and asymmetric division zones and migrate through specific phases. Nat Neurosci 7:136-144.

Nowakowski RS, Lewin SB, Miller MW (1989) Bromodeoxyuridine immunohistochemical determination of the lengths of the cell cycle and the DNA-synthetic phase for an anatomically defined population. J Neurocytol 18:311-318.

Olson LE, Roper RJ, Baxter LL, Carlson EJ, Epstein CJ, Reeves RH (2004) Down syndrome mouse models Ts65Dn, Ts1Cje, and Ms1Cje/Ts65Dn exhibit variable severity of cerebellar phenotypes. Dev Dyn 230:581-589.

Petit TL, LeBoutillier JC, Alfano DP, Becker LE (1984) Synaptic development in the human fetus: a morphometric analysis of normal and Down's syndrome neocortex. Exp Neurol 83:13-23.

Pinter JD, Brown WE, Eliez S, Schmitt JE, Capone GT, Reiss AL (2001a) Amygdala and hippocampal volumes in children with Down syndrome: a high-resolution MRI study. Neurology 56:972-974.

Pinter JD, Eliez S, Schmitt JE, Capone GT, Reiss AL (2001b) Neuroanatomy 
of Down's syndrome: a high-resolution MRI study. Am J Psychiatry 158:1659-1665.

Rakic P (1995) A small step for the cell, a giant leap for mankind: a hypothesis of neocortical expansion during evolution. Trends Neurosci 18:383-388.

Raz N, Torres IJ, Briggs SD, Spencer WD, Thornton AE, Loken WJ, Gunning FM, McQuain JD, Driesen NR, Acker JD (1995) Selective neuroanatomic abnormalities in Down's syndrome and their cognitive correlates: evidence from MRI morphometry. Neurology 45:356-366.

Reeves RH, Irving NG, Moran TH, Wohn A, Kitt C, Sisodia SS, Schmidt C, Bronson RT, Davisson MT (1995) A mouse model for Down syndrome exhibits learning and behaviour deficits. Nat Genet 11:177-184.

Richtsmeier JT, Zumwalt A, Carlson EJ, Epstein CJ, Reeves RH (2002) Craniofacial phenotypes in segmentally trisomic mouse models for Down syndrome. Am J Med Genet 107:317-324.

Roper RJ, Baxter LL, Saran NG, Klinedinst DK, Beachy PA, Reeves RH (2006) Defective cerebellar response to mitogenic Hedgehog signaling in Down [corrected] syndrome mice. Proc Natl Acad Sci USA 103:1452-1456.

Rueda N, Mostany R, Pazos A, Florez J, Martinez-Cue C (2005) Cell proliferation is reduced in the dentate gyrus of aged but not young Ts65Dn mice, a model of Down syndrome. Neurosci Lett 380:197-201.

Sago H, Carlson EJ, Smith DJ, Kilbridge J, Rubin EM, Mobley WC, Epstein CJ, Huang TT (1998) Ts1Cje, a partial trisomy 16 mouse model for Down syndrome, exhibits learning and behavioral abnormalities. Proc Natl Acad Sci USA 95:6256-6261.

Sago H, Carlson EJ, Smith DJ, Rubin EM, Crnic LS, Huang TT, Epstein CJ (2000) Genetic dissection of region associated with behavioral abnormalities in mouse models for Down syndrome. Pediatr Res 48:606-613.

Schmidt-Sidor B, Wisniewski KE, Shepard TH, Sersen EA (1990) Brain growth in Down syndrome subjects 15 to 22 weeks of gestational age and birth to 60 months. Clin Neuropathol 9:181-190.

Schneider EL, Epstein CJ (1972) Replication rate and lifespan of cultured fibroblasts in Down's syndrome. Proc Soc Exp Biol Med 141:1092-1094.

Seregaza Z, Roubertoux PL, Jamon M, Soumireu-Mourat B (2006) Mouse models of cognitive disorders in trisomy 21: a review. Behav Genet 36:387-404.

Siarey RJ, Stoll J, Rapoport SI, Galdzicki Z (1997) Altered long-term potentiation in the young and old Ts65Dn mouse, a model for Down Syndrome. Neuropharmacology 36:1549-1554.

Siarey RJ, Carlson EJ, Epstein CJ, Balbo A, Rapoport SI, Galdzicki Z (1999) Increased synaptic depression in the Ts65Dn mouse, a model for mental retardation in Down syndrome. Neuropharmacology 38:1917-1920.

Siarey RJ, Kline-Burgess A, Cho M, Balbo A, Best TK, Harashima C, Klann E, Galdzicki Z (2006) Altered signaling pathways underlying abnormal hippocampal synaptic plasticity in the Ts65Dn mouse model of Down syndrome. J Neurochem 99:1320.

Strovel J, Stamberg J, Yarowsky PJ (1999) Interphase FISH for rapid identification of a down syndrome animal model. Cytogenet Cell Genet 86:285-287.

Sylvester PE (1983) The hippocampus in Down's syndrome. J Ment Defic Res 27:227-236.

Takahashi T, Nowakowski RS, Caviness Jr VS (1995) The cell cycle of the pseudostratified ventricular epithelium of the embryonic murine cerebral wall. J Neurosci 15:6046-6057.

Takashima S, Ieshima A, Nakamura H, Becker LE (1989) Dendrites, dementia and the Down syndrome. Brain Dev 11:131-133.

Tonon G, Roschke A, Stover K, Shou Y, Kuehl WM, Kirsch IR (2000) Spectral karyotyping combined with locus-specific FISH simultaneously defines genes and chromosomes involved in chromosomal translocations. Genes Chromosomes Cancer 27:418-423.

Weitzdoerfer R, Dierssen M, Fountoulakis M, Lubec G (2001) Fetal life in Down syndrome starts with normal neuronal density but impaired dendritic spines and synaptosomal structure. J Neural Transm Suppl 2001:59-70.

Wisniewski KE (1990) Down syndrome children often have brain with maturation delay, retardation of growth, and cortical dysgenesis. Am J Med Genet Suppl 7:274-281.

Zellweger H (1977) Down syndrome. In: Handbook of clinical neurology, pp 367-469. Amsterdam: North-Holland. 